Article

\title{
A Holistic Approach to Enhance the Use of Neglected and Underutilized Species: The Case of Andean Grains in Bolivia and Peru
}

\section{Stefano Padulosi ${ }^{1}$, Karen Amaya ${ }^{2, *}$, Matthias Jäger ${ }^{2}$, Elisabetta Gotor ${ }^{1}$, Wilfredo Rojas ${ }^{3}$ and Roberto Valdivia ${ }^{4}$}

1 Bioversity International, Via dei Tre Denari 472/a, Maccarese 00057, Italy;

E-Mails: s.padulosi@cgiar.org (S.P.); e.gotor@cgiar.org (E.G.)

2 Bioversity International, Regional Office for the Americas, Recta Cali-Palmira Km. 17-CIAT, P.O. Box 6713, Cali, Colombia; E-Mail: m.jager@cgiar.org

3 Fundación PROINPA, Calle Américo Vespucio 538, Piso 3, Zona Sopocachi, Cajón Postal 1078, La Paz, Bolivia; E-Mail: w.rojas@proinpa.org

4 Centro de Investigación de Recursos Naturales y Medio Ambiente-CIRNMA, Parque Industrial Salcedo, Mz N, Lotes 11-12, Puno, Peru; E-Mail: r.e.valdivia@cgiar.org

* Author to whom correspondence should be addressed; E-Mail: k.amaya@cgiar.org; Tel.: +57-2-4450-048/49 (ext. 103); Fax: +57-2-4450-096.

Received: 28 November 2013; in revised form: 20 February 2014 / Accepted: 20 February 2014 / Published: 12 March 2014

\begin{abstract}
The IFAD-NUS project, implemented over the course of a decade in two phases, represents the first UN-supported global effort on neglected and underutilized species (NUS). This initiative, deployed and tested a holistic and innovative value chain framework using multi-stakeholder, participatory, inter-disciplinary, pro-poor gender- and nutrition-sensitive approaches. The project has been linking aspects often dealt with separately by $R \& D$, such as genetic diversity, selection, cultivation, harvest, value addition, marketing, and final use, with the goal to contribute to conservation, better incomes, and improved nutrition and strengthened livelihood resilience. The project contributed to the greater conservation of Andean grains and their associated indigenous knowledge, through promoting wider use of their diversity by value chain actors, adoption of best cultivation practices, development of improved varieties, dissemination of high quality seed, and capacity development. Reduced drudgery in harvest and postharvest operations, and increased food safety were achieved through technological innovations. Development of innovative food products and inclusion of Andean grains in school meal programs is projected to have had a positive nutrition
\end{abstract}


outcome for targeted communities. Increased income was recorded for all value chain actors, along with strengthened networking skills and self-reliance in marketing. The holistic approach taken in this study is advocated as an effective strategy to enhance the use of other neglected and underutilized species for conservation and livelihood benefits.

Keywords: holistic; value chain approach; neglected and underutilized species (NUS); Andean grains; quinoa; cañahua; amaranth; Bolivia; Peru

\section{List of Abbreviations}

$\begin{array}{ll}\text { AG } & \text { Andean Grains } \\ \text { BS. } & \text { Bolivianos (currency of Bolivia) } \\ \text { CGIAR } & \text { Consultative Group on International Agricultural Research } \\ \text { CIAL } & \text { Local Research Committee } \\ \text { CIRNMA } & \text { Centro de Investigación de Recursos Naturales y Medio Ambiente, Peru } \\ \text { FAO } & \text { Food and Agricultural Organization of the United Nations } \\ \text { GPA } & \text { Global Plan of Action } \\ \text { Ha } & \text { Hectare } \\ \text { IBNORCA } & \text { Bolivian Institute of Quality and Standardization } \\ \text { IFAD-NUS } & \text { International Fund for Agricultural Development (FIDA in } \\ \text { IK } & \text { Spanish)-Neglected and Underutilized Species } \\ \text { INDECOPI } & \text { Indigenous Knowledge } \\ \text { INIA } & \text { Protection of Intellectual Property } \\ \text { NGO } & \text { Instituto Nacional de Innovación Agraria, Peru } \\ \text { NUS } & \text { Non Governmental Organization } \\ \text { PGR } & \text { Neglected and Underutilized Species } \\ \text { PGRFA } & \text { Plant Genetic Resources } \\ \text { PIM } & \text { Plant Genetic Resources for Food and Agriculture } \\ \text { PROINPA } & \text { Policies, Institutions and Markets } \\ \text { PVS } & \text { Fundación para la Promoción e Investigación de Productos Andinos, Bolivia } \\ \text { R\&D } & \text { Participatory Variety Selection } \\ \text { SEGEDES } & \text { Research and Development } \\ \text { UCODEP } & \text { Departmental Service for Social Management, Bolivia } \\ \text { UN } & \text { Unity and Cooperation for the Development of Peoples, Italy } \\ \text { USD } & \text { United Nations } \\ & \text { United States Dollar } \\ & \end{array}$




\section{Introduction}

The Andean region is one of the richest areas in the world in terms of biological diversity. Some 45,000 species of vascular plants are estimated to grow there [1], equivalent to roughly one sixth of the world's floristic diversity. The region is also one of the main Vavilovian centers of origin of cultivated plants [2], with high genetic diversity of globally important crops and their wild relatives [3].

Paradoxically, this highly biodiverse area is also one of the poorest in Latin America (15.2\% extreme poverty rate) [4], with highest levels in the Bolivian-Peruvian plateau [5]. Of even greater concern is the high incidence of malnutrition in children under five years of age, ranging from $10 \%$ to $50 \%$ [6].

Agriculture in the Andes is characterized by a high degree of risks associated with a range of climatic stresses such as frost, hail, wind, drought, high radiation, and poor and saline soils [7]. Compared with introduced crops, native species have a comparative advantage as they are able to grow in these difficult conditions with minimum inputs as a result of selection that has been implemented by local growers over generations [8]. Their contribution to keeping agro-ecosystems more stable and healthier is recognized [8,9].

Andean rural communities have based their diet mostly on plants, using tubers, grains, cereals, legumes and fruits, and, if available, also animals (especially camelids). Agrobiodiversity is thus of high importance in their diets. Most important sources of food include Andean grains (AG), such as quinoa (Chenopodium quinoa), cañahua (Bolivian name -known as cañihua in Peru) (Chenopodium pallidicaule), amaranth or kiwicha (Amaranthus caudatus), and tarwi (Lupinus mutabilis); tubers, such as ulluco (Ullucus tuberosus), oca (Oxalis tuberosa), mashua (Tropaeolum tuberosum), and potato (Solanum tuberosum); roots, such as arracacha (Arracacia xanthorrhiza), yacón (Smallanthus sonchifolius), maca (Lepidium meyenii), camote (Ipomoea batatas); and many fruits, such as cherimoya (Annona cherimola), tree tomato (Solanum betaceum), and uvilla (Physalis peruviana) [10].

These crops are often cultivated in marginal areas. Most of their produce is kept by the growers for household self-consumption and is only occasionally sold, as in the case of quinoa, currently an important cash crop for both Bolivia and Peru. Local populations consider these crops of enormous importance for their own food and nutrition security and to meet multiple livelihood needs. Growing these native species and perpetuating their traditional cultivation and consumption practices is also particularly relevant to maintaining the bond between people and their land, culture, and traditions [11]. The wealth of indigenous knowledge (IK) on the cultivation and use of these crops represents an intangible livelihood asset, whose strategic role in reinforcing self esteem and self-reliance needs no explanation [12]. These tangible (genetic diversity) and intangible assets (IK) to Andean communities are at risk.

Globalization trends, the growth of standardized modern agriculture, which is poor in biodiversity, changes in lifestyle, such as standardization of diets, are all causing severe erosion of traditional food cultures. Political and social conflicts, as well as increasing pressure caused by climate change, are factors hindering the development of rural areas and favoring the abandonment of agriculture by younger generations $[13,14]$, which also contribute to the loss of local crops and traditions. All of these factors are having a negative impact on the breadth of agrobiodiversity used by rural populations, which in turn is limiting livelihood options, particularly of the poor. Noteworthy is also the dramatic shrinking of the food basket many of the world populations rely upon for their food security: out of 
more than 7000 species used for food, only four crops, viz. maize, wheat, rice, and potato provide over $60 \%$ of the global requirement for calories of plant origin $[14,15]$. This situation is having a strong impact on the world's overall nutrition security and dietary diversity, and was recognized in 1991 by several UN Agencies [16] as a major limitation to human development. It was again reiterated by the Millennium Development Goals Report 14 years later [17] that micronutrient deficiencies or "hidden hunger" is caused mainly by simplified diets, particularly among the poor. According to Biesalski, [18], hidden hunger is the underlying cause of numerous developmental disorders which negatively affect people's lives and their future, and ultimately aggravate their state of poverty.

There is a need to broaden the focus of agricultural R\&D to include a much wider range of crop species in order to increase livelihood options of the rural poor, including income generation, food security, and diet diversity [12]. To date, most of the plant resources with great potential to meet these goals, especially in difficult environments, have received little attention by R\&D in modern agriculture and policies. The fact that the cultivation of improved high-yielding varieties of commodity crops is also performing very poorly in marginal areas is yet another justification to broaden the portfolio of crop genetic resources in $\mathrm{R} \& \mathrm{D}[3]$.

The key milestone in the recognition of the importance of neglected and underutilized species (NUS) by the international community is represented by the first Global Plan of Action (GPA) for Plant Genetic Resources for Food and Agriculture (PGRFA) that was launched by FAO in 1996 [19] in which the promotion of these species represented one of its 12 Activities. The importance of this work was further reiterated in the second GPA [20]. The International Treaty for PGRFA has also called on countries to support the enhanced use of NUS in Art. 6 [21]. With increased awareness of the important role that NUS play in better nutrition and poverty reduction, the "Cordoba Declaration" [22] is just one of several calls most recently endorsed by scientists and policymakers advocating greater investment in these species [23].

Due to the complexity of issues involved in enhancing the use of NUS crops, it was widely felt the need for a different approach to Green revolution methods that focused mainly on staple crops and their breeding for higher yield. This was the justification behind the conception of the IFAD-NUS project: to develop and test an innovative approach for non-commodity crops, using a holistic, inter-disciplinary, inter-sector, highly participatory, pro-poor nutrition, and gender-sensitive framework. Thanks to the financial support received by IFAD, this research was made possible and successfully implemented through two distinct phases over a period of ten years.

The IFAD-NUS project is the first UN-supported global effort on neglected and underutilized species. Its goal was to demonstrate that marginalized crop genetic resources can become valid instruments of development, especially in marginal areas [24].

Between the first (2001-2005) and the second phase (2005-2009), partners included countries in Latin America (Bolivia, Peru, Ecuador), South Asia (India, Nepal), West Asia, and North Africa (Egypt, Yemen). This article focuses on the Latin American component and on Bolivia and Peru in particular. Bioversity International has been leading the project as global coordinator, whereas the national level coordination was carried out by Fundación para la Promoción e Investigación de Productos Andinos (PROINPA) in Bolivia, and by the Centro de Investigación de Recursos Naturales y Medio Ambiente (CIRNMA) in Peru. In this paper we will present the framework of the IFAD-NUS 
project, and provide insight on its results, outputs and impact, while also offering some reflections on the way forward.

\section{Experimental Section}

The holistic framework, which was followed in this work, aimed at developing new methods, approaches and tools to address issues across the inter-related segments of the value chain of target crops and to bridge the gap between conservation and use. Activities spanned from surveying, collecting and conserving genetic diversity, to the selection, cultivation, harvest, value addition, marketing, and final use of processed products (see Figure 1). By pursuing all of these activities together, the project was expected to improve income generation, leverage the nutritional benefits of target crops, and contribute to the sustainable conservation of their genetic resources.

The project design process included several meetings involving stakeholders engaged at various levels in the conservation and use of target crops.

Figure 1. Holistic value chain framework for the promotion of NUS.

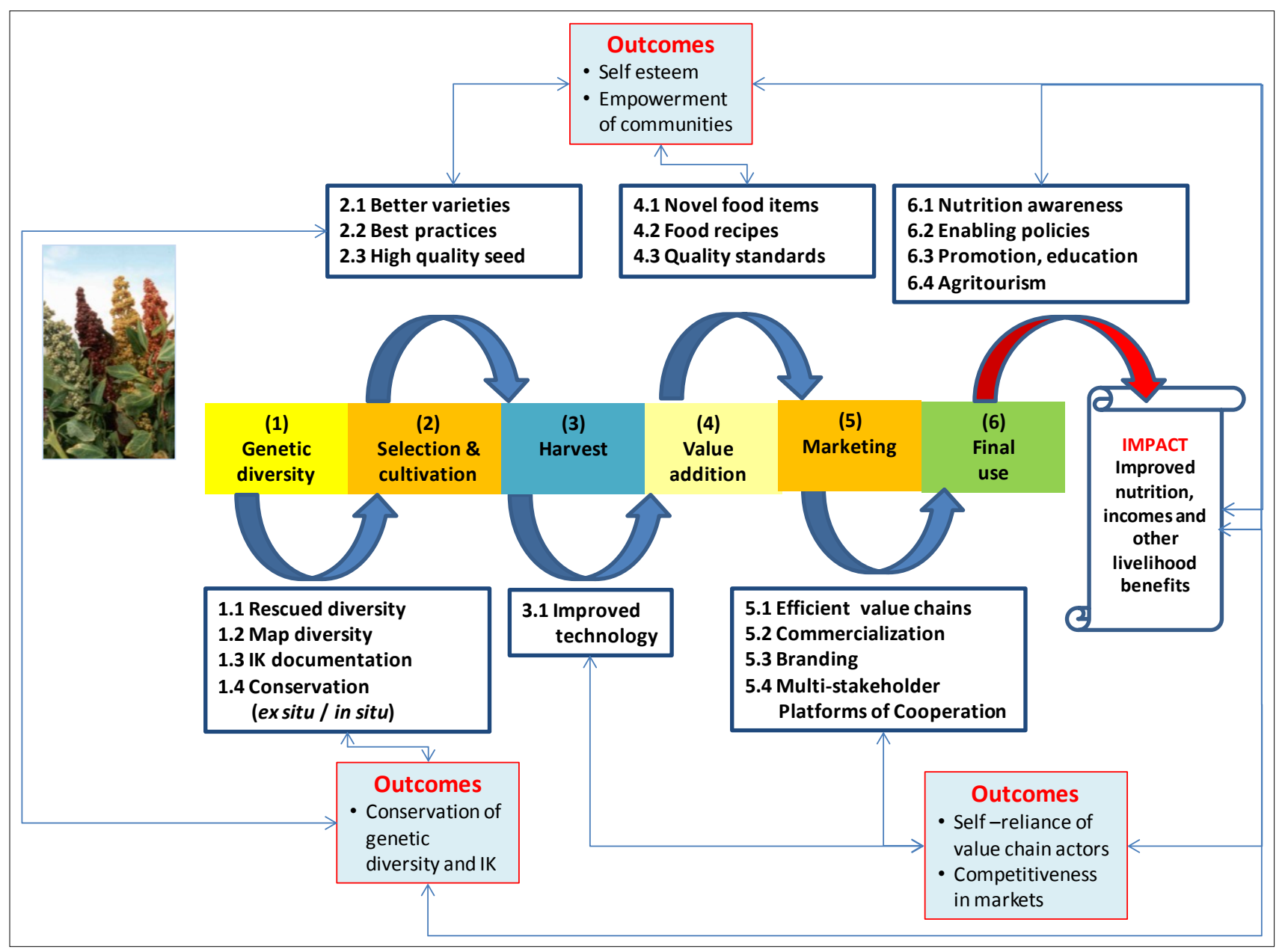

The choice of quinoa, amaranth, and cañihua as target crops for the project took place during a workshop organized in January 2001 in Bolivia that was attended by farmer associations, NGOs, research organizations and private sector representatives from Bolivia, Peru, and Ecuador (see Figures 2-4). These crops were recommended in recognition of their established use by Andean populations over 
centuries, their high nutritious profiles and strategic role in local food security, their wide genetic variability that gives them great adaptability to different environments, as well as high versatility in use, resistance to biotic and abiotic factors and low production costs [3].

Figure 2. Community garden with different quinoa varieties (Santiago de Okola, Bolivia).

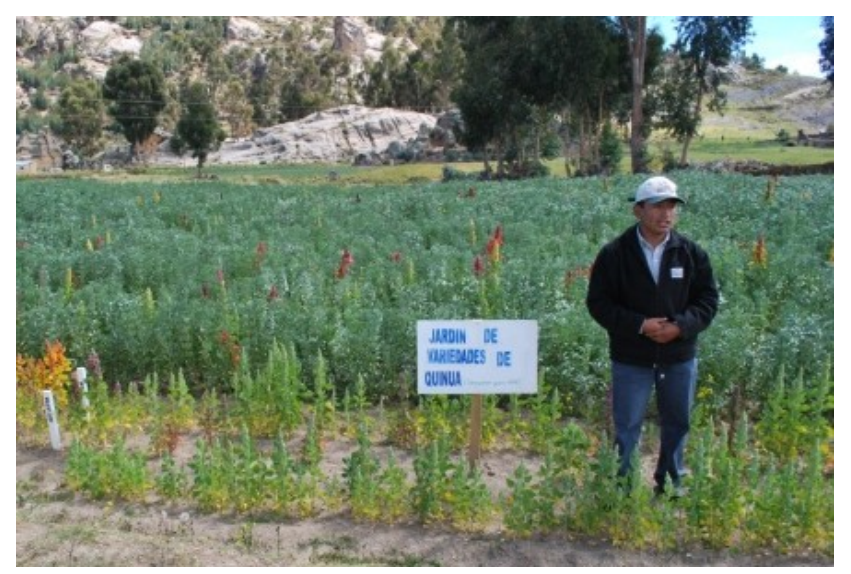

Figure 3. Farmers visiting an amaranth field during a field visit (Cusco, Peru).

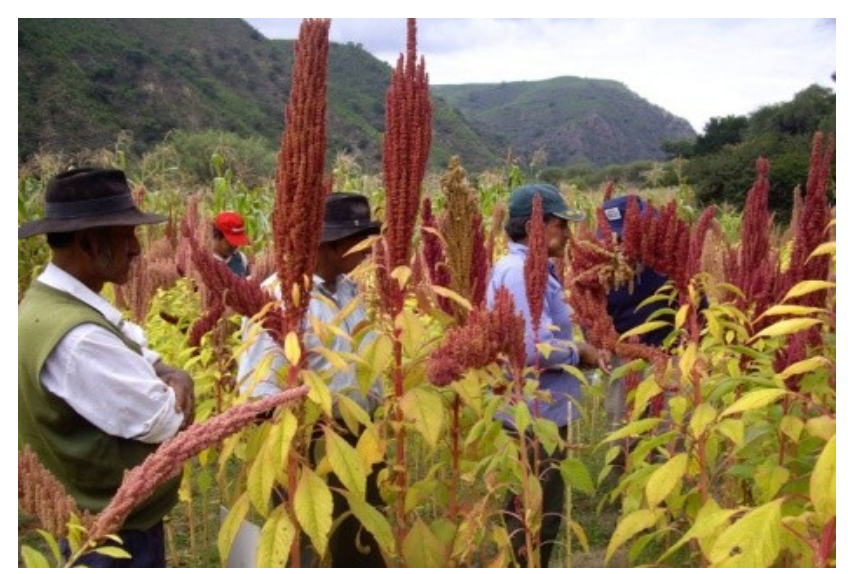

Figure 4. Farmer in her cañihua field (Sillustani Juliaca, Peru).

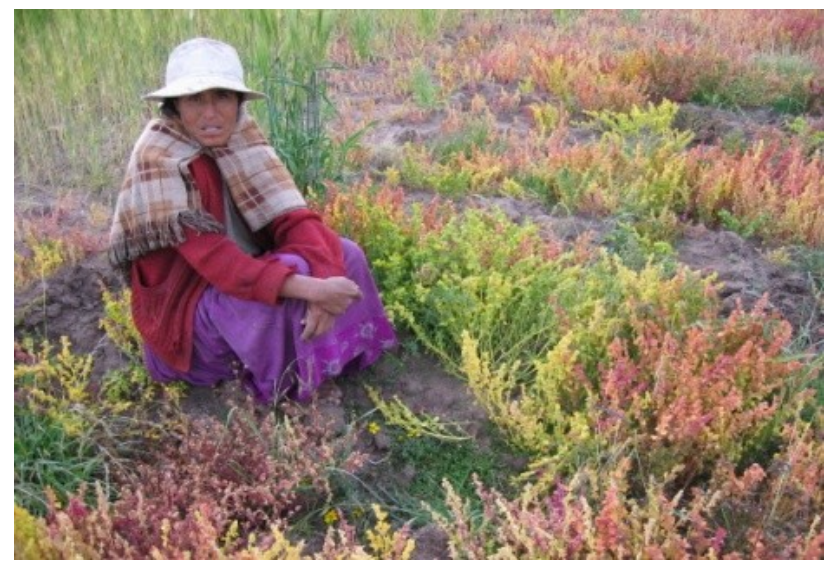

As a whole, in both Bolivia and Peru, 34 project sites were selected based on representativeness of beneficiary groups and diversity of relevance of target crops in socio-economic, cultural and geographic contexts. In total, more than 1170 families (20 to 120 families per site) participated directly 
in the implementation of the project. Special attention was given to the participation of women due to their strategic role as nutrition caretakers in the family [25].

Each year, national and regional meetings as well as frequent community-based events were organized in project sites to appraise progress, share lessons, and create necessary linkages and synergies among all stakeholders across the value chains [12]. A project steering committee also met regularly to monitor implementation. An impact assessment study was commissioned by IFAD at the end of the first phase $[25,26]$.

\section{Results and Discussion}

The domains of actions and results per value chain segment and per crop are presented in Table 1. In each of the phases, intensive capacity building efforts were deployed targeting all categories of stakeholders. Compared with the first phase, the second phase of the project dedicated greater attention on consolidating evidence regarding the contribution of target crops in food security, income generation and other livelihood benefits.

Table 1. Summary of key interventions and achievements of the IFAD-NUS project (2001-2010) in Bolivia and Peru.

\begin{tabular}{|c|c|c|c|}
\hline \multirow{2}{*}{$\begin{array}{l}\text { Value chain } \\
\text { segment }\end{array}$} & \multicolumn{3}{|c|}{ Crop } \\
\hline & Quinoa & Amaranth & Cañahua \\
\hline \multirow{2}{*}{$\begin{array}{l}\text { Genetic } \\
\text { diversity }\end{array}$} & \multicolumn{3}{|c|}{$\begin{array}{l}\text { - Eco-geographic surveying, diversity mapping, germplasm collection, genetic, and cultural } \\
\text { erosion assessments; } \\
\text { - Documentation of agro-morphological diversity; } \\
\text { - Documentation of indigenous knowledge (IK); } \\
\text { - Conservation through ex situ and in situ methods; } \\
\text { - Development of core collections; } \\
\text { - Improvement of conservation infrastructure; } \\
\text { - Capacity development of research staff in conservation-related activities; } \\
\text { - Biodiversity/seed fairs, promotion of exchange of varieties and IK }\end{array}$} \\
\hline & $\begin{array}{l}\text { - } 220 \text { quinoa accessions collected } \\
\text { in Peru; } \\
\text { INIA Genebank infrastructure } \\
\text { improvement (benefiting ca. } \\
7,000 \text { accessions of AG } \\
\text { conserved there) }\end{array}$ & $\begin{array}{l}249 \text { amaranth accessions } \\
\text { collected from } 40 \\
\text { locations across Peru } \\
\text { (largest amaranth } \\
\text { collection in the } \\
\text { Andean region) }\end{array}$ & $\begin{array}{l}\text { - Descriptors list for } \\
\text { cañahua (first to ever } \\
\text { been developed); } \\
\text { - } 83 \text { cañahua accessions } \\
\text { collected in Peru; } \\
\text { - Reintroduction of more } \\
\text { than } 40 \text { cañahua } \\
\text { accessions in farmers' } \\
\text { fields in Bolivia } \\
\end{array}$ \\
\hline $\begin{array}{l}\text { Selection, } \\
\text { cultivation, } \\
\text { harvest and } \\
\text { post-harvest }\end{array}$ & \multicolumn{3}{|c|}{$\begin{array}{l}\text { - Participatory Variety Selection (PVS) - more than } 40 \text { evaluation trials carried out in both countries; } \\
\text { - Release of improved varieties; } \\
\text { - Development of improved cultivation practices and their dissemination through diversity gardens, } \\
\text { farmers' field days, and farmers' networking; } \\
\text { - Production of good quality seeds of improved cultivars; } \\
\text { - Establishment of farmer associations for the production and marketing of AG }\end{array}$} \\
\hline
\end{tabular}


Table 1. Cont.

\begin{tabular}{|c|c|c|c|c|}
\hline \multirow{2}{*}{$\begin{array}{l}\text { Value chain } \\
\text { segment }\end{array}$} & \multicolumn{4}{|c|}{ Crop } \\
\hline & Quinoa & Amaranth & Ca & ñahua \\
\hline $\begin{array}{l}\text { Selection, } \\
\text { cultivation, } \\
\text { harvest and } \\
\text { post-harvest }\end{array}$ & $\begin{array}{l}\text { - Release of } 6 \text { improved varieties; } \\
\text { - Release of saponin-free variety } \\
\text { "INIA-415 Pasankalla" in Peru; } \\
\text { - Development of two prototype } \\
\text { post-harvest threshing machines } \\
\text { which reduced threshing time from } \\
100 \mathrm{~kg} / \text { day to } 95 \mathrm{~kg} / \mathrm{h} \text {; } \\
\text { - Development of a de-saponification } \\
\text { machine in Bolivia (reducing } \\
\text { process from } 6 \mathrm{~h} / \text { arroba to just } \\
15 \mathrm{~min} / \text { arroba) }\end{array}$ & $\begin{array}{l}\text { - Establishment of seed } \\
\text { system for amaranth in } \\
\text { project sites; } \\
\text { - Development of } 2 \text { manuals } \\
\text { on good agricultural } \\
\text { practices for amaranth }\end{array}$ & & $\begin{array}{l}\text { anease of } 2 \text { improved } \\
\text { añahu varieties in } \\
\text { olivia ("Illimani" } \\
\text { nd "Kullaca") }\end{array}$ \\
\hline \multirow[b]{2}{*}{ Value addition } & \multicolumn{4}{|c|}{$\begin{array}{l}\text { - Development of new processing technologies for both home consumption and market purposes; } \\
\text { - Characterization of germplasm collections for nutritional and other valuable market traits; } \\
\text { - Development of novel food recipes using specific ecotypes leveraging different cooking attitudes; } \\
\text { - Workshops and fora for dissemination of methods; } \\
\text { - Development of technical regulations that defined, classified and established requirements } \\
\text { regarding the commercialization of AG (which are now facilitating access of AG products to } \\
\text { international markets) }\end{array}$} \\
\hline & $\begin{array}{l}\text { - Technical innovation for AG } \\
\text { popping machines (solving } \\
\text { hazardous led contamination in } \\
\text { popped products which was found } \\
\text { ranging from } 1.5 \text { to even } 50 \text { times } \\
\text { the total lead content considered as } \\
\text { safe for human food consumption } \\
\text { by FAO's Codex Alimentarius); } \\
\text { - Documentation and publication } \\
\text { of traditional recipes for } \\
\text { cooking quinoa; } \\
\text { - Production of } 18 \text { novel food items; } \\
\text { - Production of innovative new } \\
\text { recipes such as pre-cooked quinoa } \\
\text { soup and quinoa beer }\end{array}$ & $\begin{array}{l}\text { - Development of amaranth } \\
\text { energy bars in Bolivia (which } \\
\text { are now included in school } \\
\text { feeding programs helping } \\
\text { improve children' nutrition ar } \\
\text { generating additional income } \\
\text { all the actors involved in the } \\
\text { amaranth value chain- estima } \\
\text { to be approx. } 400 \mathrm{k} \text { USD/year } \\
\text { the area of Chuquisaca alone) } \\
\text { - Study carried out in } 2009 \text { in } \\
\text { Bolivia showed improved hea } \\
\text { status of } 44 \text { school children } \\
\text { attributable to amaranth } \\
\text { consumption promoted by } \\
\text { the project; } \\
\text { - Documentation and publicati } \\
\text { of traditional recipes for cook } \\
\text { quinoa and cañahua; } \\
\text { - Production of } 10 \text { novel } \\
\text { food items; } \\
\text { recipes as amaranth ice-crean }\end{array}$ & & $\begin{array}{l}\text { - Production of } 15 \\
\text { novel food items; } \\
\text { - Production of } \\
\text { innovative new } \\
\text { recipes such as } \\
\text { cañahua protein } \\
\text { isolate and } \\
\text { cañahua flan; } \\
\text { - Documentation of } \\
20 \text { different types of } \\
\text { recipes using cañahua }\end{array}$ \\
\hline
\end{tabular}


Table 1. Cont.

\begin{tabular}{|c|c|c|c|}
\hline \multirow[b]{2}{*}{$\begin{array}{l}\text { Value chain } \\
\text { segment }\end{array}$} & \multicolumn{3}{|c|}{ Crop } \\
\hline & Quinoa & Amaranth & Cañahua \\
\hline \multirow[b]{2}{*}{ Marketing } & \multicolumn{3}{|c|}{$\begin{array}{l}\text { - Analyses of value chains and development of upgrading strategies through vertical and } \\
\text { horizontal coordination; } \\
\text { - Branding of new products involving communities; } \\
\text { - Dissemination of recipe books; } \\
\text { - Strengthening of linkages between farmers and private sector; } \\
\text { - Establishment of multi-stakeholder platforms of cooperation; } \\
\text { - Exploration of novel market options for AG such as gluten free, biological agriculture, diabetic/low } \\
\text { glycaemic index products, nutraceutical uses for development of more attractive and high-value } \\
\text { food items }\end{array}$} \\
\hline & $\begin{array}{l}\text { Establishment of strategic } \\
\text { partnership with Alexander Coffee } \\
\text { Shop Chain in Bolivia (launching } \\
\text { a pro-AG campaigns during which } \\
\text { customers were informed about } \\
\text { the nutritional benefits of AG } \\
\text { through leaflets, table-tents and } \\
\text { posters and by tasting attractive } \\
\text { and innovative modern food } \\
\text { recipes based on AG). }\end{array}$ & $\begin{array}{l}\text { Establishment of an Amaranth } \\
\text { Platform in Bolivia where all } \\
\text { value chain actors in } \\
\text { Chuquisaca area are now } \\
\text { effectively cooperating with } \\
\text { substantial economic gains; } \\
\text { - Approval of the National } \\
\text { Bolivian Amaranth } \\
\text { Development Plan supported } \\
\text { by the Bolivian Government }\end{array}$ & $\begin{array}{l}\text { Establishment of direct } \\
\text { linkages between } \\
\text { Alexander Coffee and } \\
\text { poor farming } \\
\text { communities from Lake } \\
\text { Titicaca for the supply } \\
\text { of cañahua } \\
\text { raw material }\end{array}$ \\
\hline $\begin{array}{l}\text { Capacity } \\
\text { building, } \\
\text { education and } \\
\text { public } \\
\text { awareness }\end{array}$ & \multicolumn{3}{|c|}{$\begin{array}{l}\text { - Carried out at various levels and supported by factsheets, manuals, recipe books, scientific articles, } \\
\text { lecturing at high school and University levels; } \\
\text { - Lobbying for supportive policies to mainstreaming best practices made at national and } \\
\text { international level; } \\
\text { - Nutritional analyses as well as biochemical characterization of germplasm for polyphenols, } \\
\text { antioxidants and other nutraceutical traits were carried out for quinoa, cañahua, and amaranth in } \\
\text { each country; } \\
\text { - Farmers, farmers' associations, extension workers received training on the nutritional benefits of } \\
\text { AG, best cultivation practices incl. production of quality seeds, pest and disease management and } \\
\text { improved harvest and post-harvest methods; novel food preparations, transformation processes, } \\
\text { food safety, and marketing; } \\
\text { - } 30 \text { students from local universities in Bolivia and Peru carried out their research thesis in the } \\
\text { framework of the IFAD NUS project; } \\
\text { - Launching of innovative agritourism approach in Santiago de Okola (Bolivia); training for men and } \\
\text { women and provision of simple infrastructure for hosting tourists, museum on agrobiodiversity, } \\
\text { web site; all activities now self-sustainable and contributing to raise incomes of community } \\
\text { members and safeguard NUS diversity and IK. }\end{array}$} \\
\hline
\end{tabular}

\subsection{Genetic Diversity}

As stressed by several workers [3,23,27,28], NUS are poorly represented in ex situ genebank collections, such that use-enhancement interventions usually require a special effort to collect genetic 
diversity. The project documented both cultivated and wild genetic resources of the target crops by carrying out surveys and collecting missions in the five agrobiodiversity microcenters located around Lake Titicaca. During these surveys IK associated with the crops were also documented. These activities improved the understanding of the crops' current ecogeographic distribution and threats to both their genetic and cultural diversity [29,30].

The first descriptors list for cañahua was developed to help characterize collections and promote use enhancement of this crop by breeders and farmers [31]. A revision of the descriptors list for quinoa was also carried out [32]. Upgrading of national seed collections of AG in both countries was supported to improve the ex situ conservation capacities for these crops. Long-term storage protocols for seeds, better documentation systems, regeneration of collections, implementation of core collections, and better taxonomic identification of wild relatives of target species were also carried out. The collections made through the project contributed to a sizeable increase of genetic material of target crops, including samples from areas that were previously unexplored. For instance, in Bolivia, 220 accessions of quinoa and 83 of cañahua were collected. In Peru, 250 germplasm accessions of amaranth were collected from Cusco, Ayacucho and Apurimac regions. At the INIA station, the project contributed to assembling the largest amaranth collection in the Andean region (249 accessions conserved from nearly 40 locations from across Peru) [33-35], as well as rejuvenation and characterization of 210 accessions of this crop. Infrastructure improvement of the INIA genebank during the project has also benefited approximately 7,000 accessions of AG conserved in the facility (Figure 5).

Figure 5. Germplasm bank—Illpa, INIA-Puno, Peru.

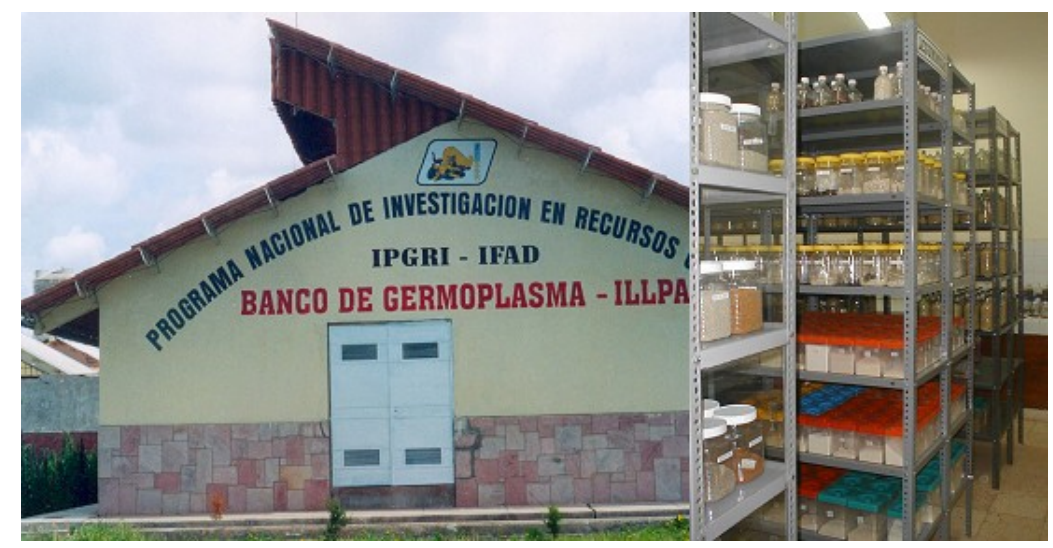

The eco-geographic surveys detected high degree of genetic erosion in farmers' fields for quinoa, cañahua and amaranth in both countries. For instance, the survey carried out in 2003 in the Department of La Paz, Bolivia, involving 467 families across five provinces revealed that out of 200 cultivars of AG previously recorded from this region, only 40 cultivars of quinoa and 20 cultivars of cañahua were remaining. Moreover, $85 \%$ of the farmers cultivated only one landrace of cañahua. Thanks to previous collections made on cañahua, the project was able to successfully re-introduce in Bolivia more than 40 accessions of this crop, which is now in greater demand by farmers because of its cold resistance [12].

At least five diversity fairs were carried out in each country to promote the exchange of genetic material among farmers together with associated IK. During these events the project gathered information on traditional food preparations, in particular through documentation of women's traditional recipes [36], which were then disseminated through training courses and workshops to communities. An indication 
of the up-taking of food recipes promoted by the project is represented by the noticeable increase in the number of food preparations displayed at the Biodiversity Fairs held in Tiwanaku (Bolivia) from 2002 to 2004 (Table 2). The documentation of women's traditional recipes helped raise greater awareness and appreciation for their role in maintaining local bio-cultural heritage [36].

Table 2. Preparations of quinoa and cañahua documented at the Biodiversity Fairs held in Tiwanaku (Bolivia) in 2002, 2003, and 2004.

\begin{tabular}{|c|c|c|c|c|}
\hline \multirow{2}{*}{$\begin{array}{l}\text { Product } \\
\text { category }\end{array}$} & \multicolumn{4}{|c|}{ Food preparations recorded during the Fairs } \\
\hline & 2002 & 2003 & & 2004 \\
\hline Beverages & Quinoa drink & $\begin{array}{l}\text { Quinoa drink; } \\
\text { Cañahua drink }\end{array}$ & $\begin{array}{l}\text { Quinoa drink; } \\
\text { "Kusa de quinua”; } \\
\text { "Api" }\end{array}$ & $\begin{array}{l}\text { Quinoa with milk; } \\
\text { Cañahua drink }\end{array}$ \\
\hline $\begin{array}{l}\text { Soups } \\
\text { and other } \\
\text { savoury } \\
\text { products }\end{array}$ & $\begin{array}{l}\text { "P'esque de } \\
\text { quinua"; } \\
\text { Quinoa soup }\end{array}$ & $\begin{array}{l}\text { Quinoa in grains; } \\
\text { "Torrejas de } \\
\text { quinua"; } \\
\text { "P'esque de } \\
\text { quinua"; } \\
\text { Quinoa soup }\end{array}$ & $\begin{array}{l}\text { P'esque with milk; } \\
\text { "Jupha tanta"; } \\
\text { "Segundo de quinua"; } \\
\text { "Pesque huracha"; } \\
\text { "Pisara"; } \\
\text { Quinoa soup; } \\
\text { "Lawa (allpi)"; } \\
\text { "Huaricha", }\end{array}$ & $\begin{array}{l}\text { P'esque with cañahua; } \\
\text { "P'esque con ahugado"; } \\
\text { "Saise de quinua"; } \\
\text { Meatballs; } \\
\text { "Plato a la huancaina" } \\
\text { "Muchacha"; } \\
\text { "Lawa de cañahua" }\end{array}$ \\
\hline Pastries & $\begin{array}{l}\text { "Pito de } \\
\text { quinua"; } \\
\text { "Kispiña" }\end{array}$ & $\begin{array}{l}\text { "Kispiña de } \\
\text { quinua"; } \\
\text { "Tayacha de } \\
\text { cañahua"; } \\
\text { "Pito de quinua" }\end{array}$ & $\begin{array}{l}\text { "Pito de cañahua"; } \\
\text { "Q'api kispiña" } \\
\text { "K'iqui kispiña"; } \\
\text { "Acu kispiña”; } \\
\text { "Kispiña"; } \\
\text { "Kispiña de ajara"; } \\
\text { Quinoa cake; } \\
\text { Quinoa omelette; } \\
\text { "Buñuelos de quinua"; } \\
\text { "Kispiña tostada" }\end{array}$ & $\begin{array}{l}\text { "Jupha kispiña”; } \\
\text { "K'api kispiña”; } \\
\text { "Piri”; } \\
\text { "Mukuna”; } \\
\text { "Wila quispiña"; } \\
\text { "Cañahua omelette”; } \\
\text { "Buñuelo de cañahua"; } \\
\text { Cañahua cake; } \\
\text { Cañahua cookies } \\
\text { Quinoa cookies }\end{array}$ \\
\hline
\end{tabular}

Non-food uses associated with Andean grains were also documented during the Fairs. Interesting uses included the medical applications: farmers mentioned that "pito de cañahua" is an effective means to control altitude sickness or diarrhoea, and quinoa cataplasm is a valid cure for dislocations and bone fissures. Furthermore, religious offerings made with quinoa and cañahua to Pachamama (Mother Earth in Andean beliefs) were also believed to purify the environment [36,37].

These agrobiodiversity Fairs, carried out in the five microcenters included contests and prizes that were given to farmers, which served as motivation for their continued conservation of local varieties [38] (see Figure 6). Due to the success of these events in promoting both local agrobiodiversity and cultural identity, a number of local Municipalities appreciated their importance and agreed to institutionalize them as annual events [29,30,37,39].

In situ conservation was also promoted during the project through social recognition of custodian farmers who made exceptional contribution to the conservation of local diversity [40]. The public recognition was expected to encourage their continued contribution by raising their self-esteem. 
Figure 6. Biodiversity contest of Andean grains, Bolivia.

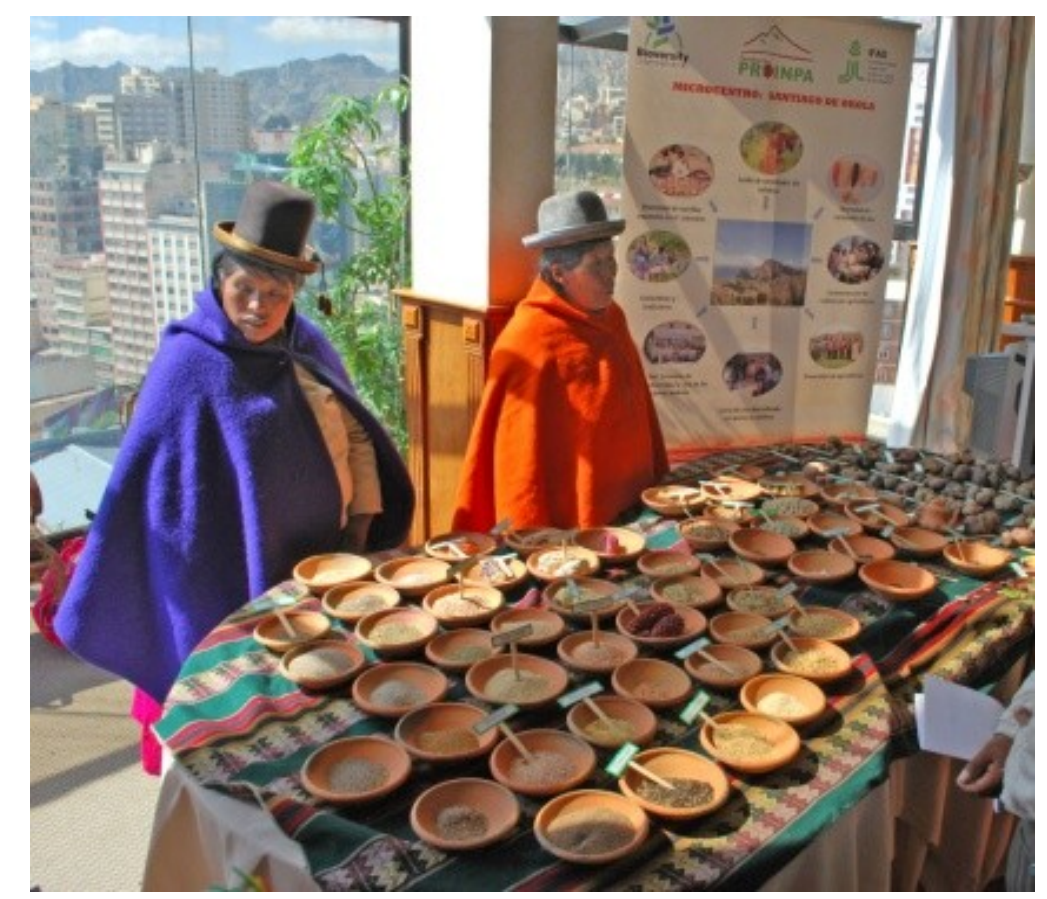

\subsection{Selection, Cultivation, Harvest and Post Harvest}

One of the largest bottlenecks in the use of AG is the lack of genetic material with commercially valuable market traits $[8,41,42]$. Therefore, numerous workshops and more than 40 participatory selection trials for cultivars of quinoa, cañahua, and amaranth were carried out in both countries in which diversity was assessed according to farmers' preferences, considering market and other livelihood needs. Accessions showing greatest potential in the different areas were selected [29,37]. At least eight Local Research Committees (CIAL) were established to work on these activities. Demonstration plots were created to which farmers carried out field visits and exchange experiences. This work spread over a 10-year period, led to the successful release of six improved cultivars of quinoa. Of these, an interesting saponin-free cultivar, the "INIA-415 Pasankalla", was released in Peru [43]. Moreover, two improved cañahua cultivars, the "Illimani" [44] and "Kullaca" [45] (see Figure 7a,b), were the first improved varieties of this crop that have ever been released. They showed characteristics, such as precocity and uniformity in color and size of the grain, important traits not usually found in local varieties.

At the start of the project, formal seed production, especially for amaranth, was non-existent in target countries, and therefore initiative was taken to build and strengthen the seed supply system in several locations. To assure self-sustainable production of good quality seed of target crops, farmers were trained in high quality seed production, which is being implemented now, independently and sustainably, by several farmer associations [12].

During the second phase, special attention was given to assess pests and diseases affecting amaranth production in the main producing areas. Using a combination of traditional and modern approaches, best practices to control and reduce crop damage were determined that reduced the use of pesticide in the range of $50 \%$ to $90 \%$. Two manuals regarding these methods were published and disseminated to farmers [46,47]. Interestingly, these were the first manuals ever to have been developed for this crop in Bolivia or Peru in spite of the centuries-old cultivation of this crop in these countries. 
Figure 7. Factsheet of two of the first ever released improved varieties of cañahua in Bolivia: (a) Cañahua Illimani and (b) Cañahua Kullaca.

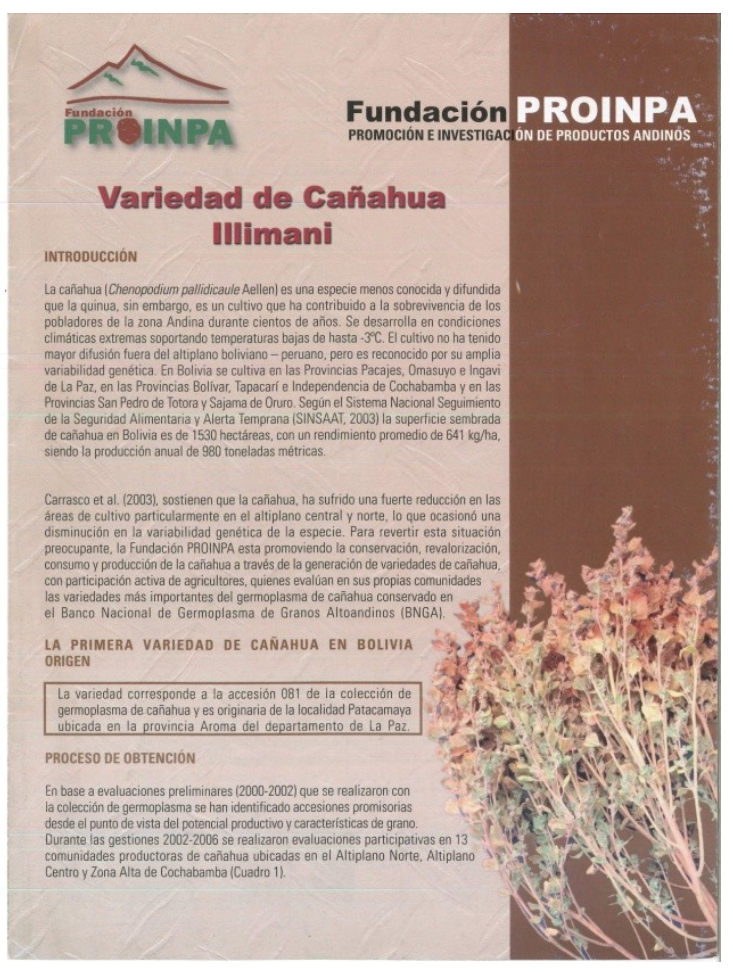

(a)

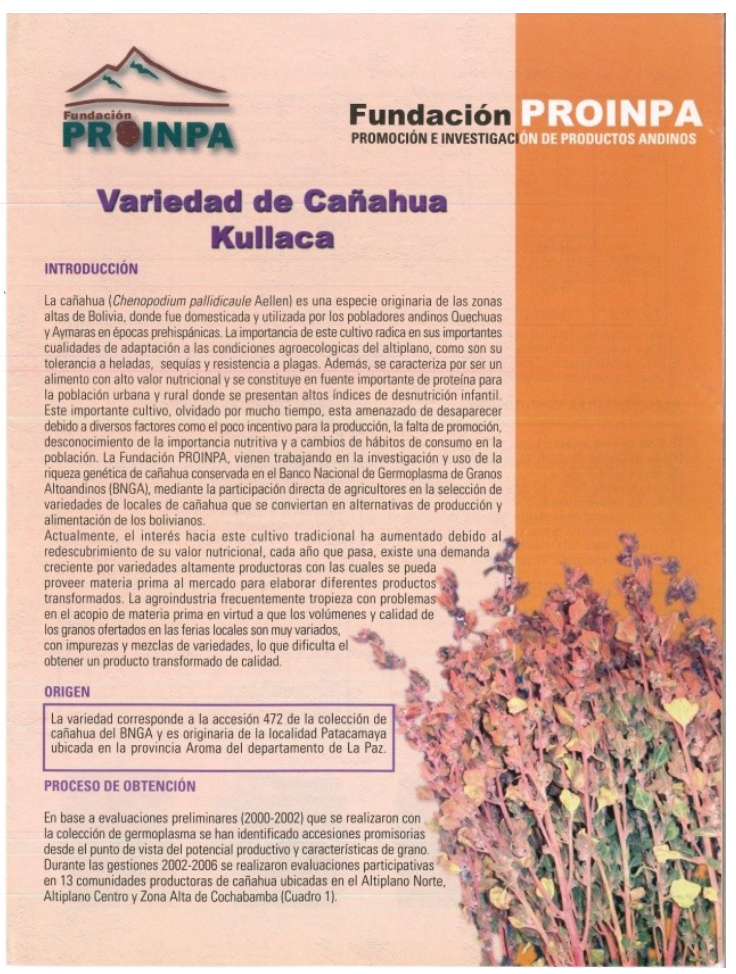

(b)

With regard to harvest, participatory surveys showed that major bottlenecks for target crops were related to harvest/post harvest operations $[8,41,42]$. In amaranth, initial surveys revealed that grain loss during harvest and postharvest was up to $15 \%$. Therefore, special attention was given by the project to develop enhanced technology to improve these operations.

In Bolivia, two prototype post harvest machines to thresh Andean grains, especially quinoa were designed, constructed, and validated, and another was validated in Peru (Figure 8). One of the threshing prototypes provided great improvement in performance with considerable time-savings: in the case of quinoa, threshing time was reduced from $100 \mathrm{~kg}$ /day using the traditional technique to $95 \mathrm{~kg} / \mathrm{h}$. With regard to the de-saponification machine (Figure 9), time-saving was also conspicuous as it was reduced from $6 \mathrm{~h}$ per arroba (local volume unit equivalent to 30.46 liters in Bolivia) to just 15 min [37]. These innovations have also addressed other problems, such as contamination by stones and sand, loss of grain, difficult transportation to the field, and the high price of machines. The new technology has allowed farmers to process small and medium operations, where previously machines were only available for large-scale operations and were thus out of reach to these users. Thanks to new methods and tools introduced by the project, in the Curawasi area (the largest amaranth producing area in the Apurimac region of Peru), the area planted to amaranth has expanded nearly five times (cultivation area rising from 8 ha recorded in 2005 to 50 ha in 2009) [25].

Equipment for the de-saponification of quinoa seeds in Bolivia was also validated in close participation with community members. The de-saponification prototype has had a strong benefit for women in particular, as they are the ones in charge of this operation within their communities. The machines reduced drudgery associated with processing quinoa and thereby contributed to empowering 
women and elevating their social status and self esteem, as they are now able to dedicate less time on this work and earn extra income from value addition [29,37].

Figure 8. Innovative threshing machine prototype used for amaranth, Peru.

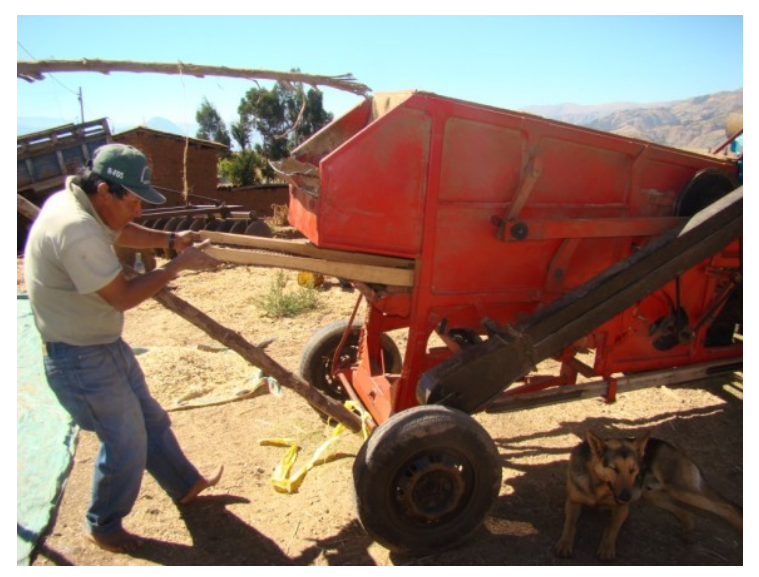

Figure 9. Women Association using the project's innovative de-saponification machine prototype, Bolivia.

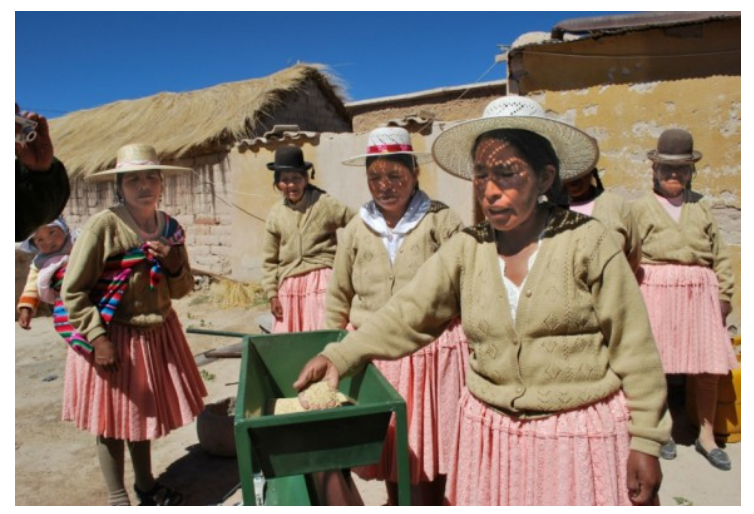

\subsection{Value Addition}

Participatory surveys indicated that value addition for quinoa, cañahua, and amaranth was another major bottleneck in their respective value chains [29,37].

In appraising these limitations during the project, an important finding was made regarding hazardous processing in popped grains, which are commercialized throughout Bolivia and Peru. The study found large quantities of lead in popped AG, in amounts that ranged from 1.5 to even 50 times the total lead content considered safe for human food consumption by FAO's Codex Alimentarius. A large portion of the urban population consumes these products, especially children, so the project realized the need for an urgent solution. With the help of engineers a new popping machine similar to the ones found locally was developed [48]. However, this equipment was more expensive than those produced locally. A more adequate and accessible technological innovation for the farmers was therefore conceived in the form of a Teflon lid to replace the one made of lead (see Figure 10). This innovation reduced the amount of lead found in popped products to a safe level as per the Codex indications. However, this innovation was only introduced to a small number of processing companies, so more work is needed to encourage wider adoption. 
Figure 10. Popping machine prototype similar to the ones found locally that reduces lead values in the product processed.

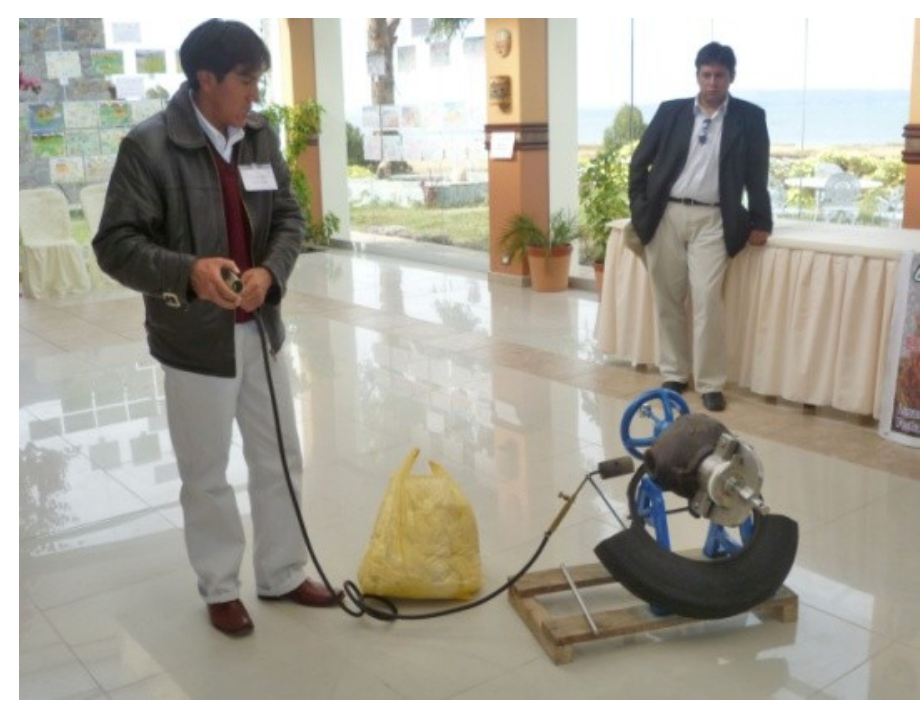

In Bolivia, strategic alliances with private companies were established to promote the development of new products made of AG. Particularly noteworthy was the collaboration on amaranth, whose accessions proved to be suitable for the development of specific food applications, including energy bars, produced as a novel and attractive food product for children. Such a product is now included in the school feeding programs of cities, such as Sucre and Serrano in the department of Chuquisaca. This new snack contributed to increase the popularity of amaranth among children over more attractive but less nutritious cereal-based items. This activity also generated additional income for the actors involved in the value chain of amaranth. According to project data, such use enhancement of amaranth generated an increase in yield from 800 to $1300 \mathrm{~kg} / \mathrm{ha}$ with an enhancement in economic benefits in the order of at least 3 mil Bolivianos/year (app. 400,000 USD) for the whole amaranth value chain sector operating in the area of Chuquisaca.

Another activity to promote the use of AG and contribute to strengthen the nutrition security in Bolivia using target species was the development of new products based on quinoa, cañahua, and amaranth. Thanks to this product diversification strategy there has been an increased number of AG products available in supermarkets such as meatballs, cakes, juices, pancakes, among many others (see Figure 11). In total, around 18 items using quinoa, 15 using cañahua, and 10 using amaranth have been developed. As traditional recipes were documented and promoted, new alternative food recipes were also explored such as pre-cooked quinoa soup, quinoa beer, cañahua protein isolate, cañahua flan, amaranth ice-cream, and quinoa nectar, which recorded a very good acceptance by final consumers $[49,50]$. Fortified cookies and dairy substitutes, based on AG, are now being provided to breastfeeding women in governmental programs [12].

Nutritional analysis and tests for assessing germplasm accessions were made to ascertain the nutritional values in raw and processed products.

Surveys were developed to document IK regarding traditional uses. Traditional recipes were collected, consolidated and published as traditional recipes books for cooking quinoa, cañahua, and amaranth [36,51-53]. It was interesting to find in the Bolivian high plateau alone, at least 37 different recipes prepared with quinoa, out of 100 food uses reported in the literature as a whole for this crop [54]. 
Figure 11. New food items prepared with Andean grains.

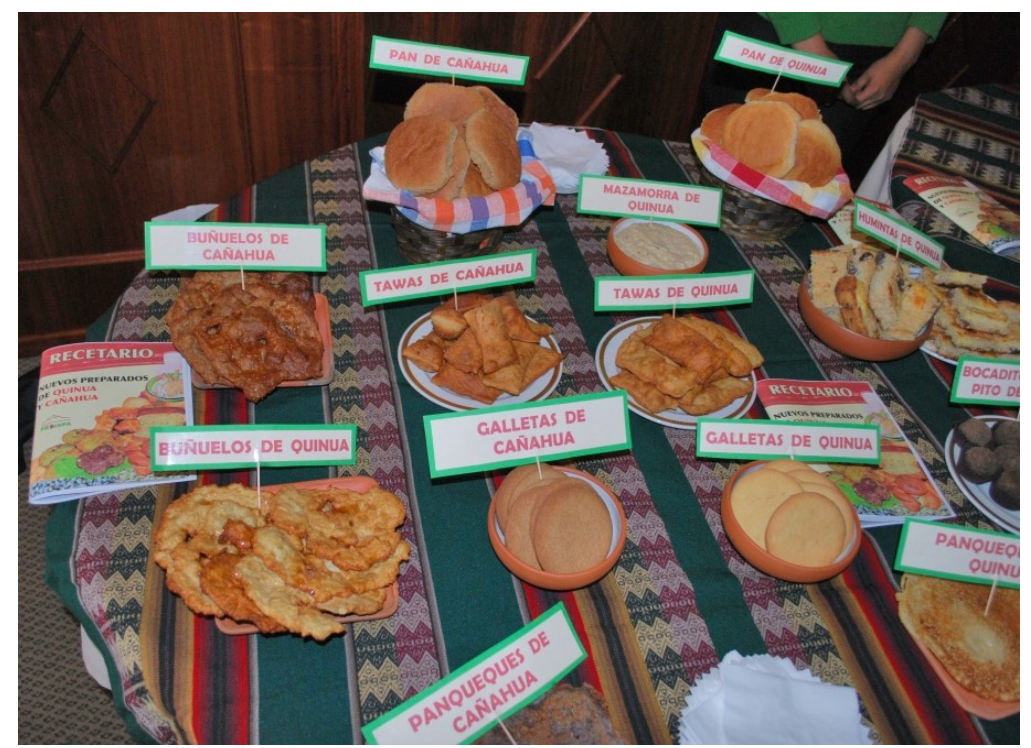

Twenty different types of recipes using cañahua were also compiled. Recipes compiled were used to support promotional campaigns of these crops in which the high nutritional value of these crops was emphasized. In this regard, it is interesting to note that the 18 surveys carried out by the project in urban and rural areas of Bolivia showed that at least $70 \%$ of people interviewed were completely unaware of the nutritional benefits of AG, which have been replaced by more-easy-to-prepare, less nutritious and easy to acquire products made of cereals. As compared to cereals, AG shows very high levels of some essential amino acids (Table 3).

With regard to the nutritional contribution of amaranth, a study carried out by the project in 2009 in Bolivia in cooperation with SEDEGES (Departmental Service for Social Management) and targeting 44 school children, showed improved health status of participating children [55-57].

Table 3. Comparison of the nutrient profile of various Andean Grains and cereals.

\begin{tabular}{|c|c|c|c|c|c|c|}
\hline Variable & Quinoa & Cañihua & Amaranth & Barley & Wheat & Maize \\
\hline Carbohydrates (g/100 g) & $67-70^{\bullet}$ & $65-68.4 *$ & $65.1^{\bullet}$ & $58.32 *$ & $78.4^{\bullet \bullet}$ & $81.1^{\bullet}$ \\
\hline Raw fibre (g/100 g) & $3.1-7^{\bullet}$ & $5.1-5.7 *$ & $6.7^{\bullet}$ & $9.4-10.2^{\bullet}$ & $3 * *$ & $9.2 * *$ \\
\hline Fat $(g / 100 \mathrm{~g})$ & $8.9-12.9 *$ & $3.5-5^{\bullet}$ & $7.2^{\bullet}$ & $6.15 *$ & $2.3^{\bullet}$ & $4.7^{\bullet}$ \\
\hline Proteins (g/100 g) & $15-15.8 *$ & $13.9-16.8 *$ & $12.9^{\bullet}$ & $12.6 *$ & $14.3^{\bullet \bullet}$ & $10.2^{\bullet}$ \\
\hline Calcium (mg/100 g) & $80-124^{\bullet}$ & $125.8-195.4 *$ & $179^{\bullet}$ & $20^{\bullet \bullet}$ & $50.3^{\bullet}$ & $17.1^{\bullet}$ \\
\hline Iron $(\mathrm{mg} / 100 \mathrm{~g})$ & $3.6-6.5 *$ & $16.7-41.3 *$ & $5.3^{\bullet}$ & $3 \bullet$ & $3.8^{\bullet}$ & $2.1^{\bullet}$ \\
\hline \multicolumn{7}{|c|}{ Essential amino acids (\% per g of protein): } \\
\hline Isoleucine & $6.88-7.05^{\bullet}$ & $5.8-6.84^{\bullet}$ & $5.17-6.17^{\bullet}$ & $3.2^{\bullet}$ & $3.2^{\bullet}$ & $3.2^{\bullet}$ \\
\hline Leucine & $10.4^{\bullet}$ & $5.44-6.08^{\bullet}$ & $4.23-5.2^{\bullet}$ & $6.3^{\bullet}$ & $6.0^{\bullet}$ & $10.3^{\bullet}$ \\
\hline Lysine & $7.9^{\bullet}$ & $5.07-6.28^{\bullet}$ & $6.43-7.16^{\bullet}$ & $2.4^{\bullet}$ & $1.5^{\star}$ & $2.7^{\bullet}$ \\
\hline Phenylalanine & $5.9^{\bullet}$ & $3.18-3.72^{\bullet}$ & $3.27-3.98^{\bullet}$ & $3.7^{\bullet}$ & $3.4^{\bullet}$ & $3.3^{\bullet}$ \\
\hline Methionine & $1.98-2.2^{\bullet}$ & $1.4-1.71^{\bullet}$ & $2.13-2.45^{\bullet}$ & $1.3^{\bullet}$ & $1.0^{\bullet}$ & $1.6^{\bullet}$ \\
\hline Threonine & $4.5-4.52^{\bullet}$ & $4.41-4.89^{\bullet}$ & $4.73-5.38^{\bullet}$ & $3.2^{\bullet}$ & $2.7^{\bullet}$ & $3.9^{\bullet}$ \\
\hline Tryptophan & $1.6^{\bullet}$ & $0.74-0.85^{\bullet}$ & $0.95-1.21^{\bullet}$ & $1.1^{\bullet}$ & $0.6^{\star}$ & $0.5^{\bullet}$ \\
\hline Valine & $7.6^{\bullet}$ & $4.25-4.72^{\bullet}$ & $4.36-4.61^{\bullet}$ & $4.6^{\circ}$ & $3.7^{\bullet}$ & $4.9^{\circ}$ \\
\hline
\end{tabular}

Sources: * [58]; ** [59]; ${ }^{\bullet}[60] ;{ }^{\bullet}[61] ;{ }^{\bullet}[62] ;{ }^{\bullet \bullet}[63]$. 
The lack of quality standards in the value chains of AG that was demonstrated in the case of popped $\mathrm{AG}$ is a factor that hinders the marketing of quinoa, cañahua, and amaranth. Workshops were held during the project with representatives of the Bolivian and Peruvian Ministries of Agriculture and Commerce and private sector actors to discuss ways to fill this normative gap. The project worked in close collaboration with the Bolivian Institute of Quality and Standardization (IBNORCA) [64], the Peruvian National Institute for the Defense of Competition and the Protection of Intellectual Property-INDECOPI [65], and other actors in AG value chains to develop the first technical regulations that define, classify and establish requirements regarding the commercialization of these crops in each country, while promoting diversity of target crops in production systems $[57,66]$. This norm is now facilitating access of AG products to international markets. These norms were subsequently used as a basis for the development of technical regulations for the Andean region through the support of the Interamerican Development Bank.

\subsection{Marketing}

Market, commercialization, and demand limitations are key aspects in the promotion of any NUS, including AG. Very often these limitations are due to the stigma of food-of-the-poor that so often accompany these traditional crops in any country. Consistent efforts by the IFAD-NUS project were therefore invested to popularize the consumption of AG in ways that would cast on them a more positive image. The most successful intervention of this nature was the strategic partnership developed with the Bolivian private coffee-shop chain "Alexander Coffee". This joint venture was the result of a collaboration between PROINPA, the Bolivian-based ecotourism NGO "La Paz on foot", the Italian NGO UCODEP (today Oxfam-Italy), and Bioversity International. This alliance launched pro-NUS campaigns where customers in Alexander Coffee shops across Bolivia were informed about the nutritional benefits of AG through attractive leaflets, table-tents, posters, and, of course, through the tasting of attractive and innovative modern food recipes [67] (see Figure 12). The snacks, biscuits, and other food items using AG developed with the support of Alexander Coffee's chefs were a great success and are now very popular items in the circuit of this catering chain with spill-over effects in other shops. At the same time, this initiative promoted the establishment of direct linkages between Alexander Coffee and poor farming communities from Lake Titicaca for the supply of raw material [68].

Surveys on consumer preferences of AG in Bolivia and Peru were carried out to gain better insights on their potential in different market segments. At the same time, other efforts were spent to establish sustainable linkages and strategic partnerships between farmers and the private sector (such as Naturalcos, Bolivia Natural companies). In these collaborative works, the relevance of emerging market options for AG through gluten-free, organic agriculture, diabetic/low glycemic index, and nutraceutical products were explored for development of more attractive and high-value food items.

Due to a poor or complete lack of linkages across actors of AG value chains, multi-stakeholder cooperation platforms for quinoa, cañahua, and amaranth were created in 2009, in both Bolivia and Peru (see Figure 13). Objectives of these platforms included [8,41,42]:

- Participatory mapping of relevant actors and their function within the value chain;

- Joint assessment of existing constraints and bottlenecks;

- Development of upgrading strategies, action plans, up-scaling tools and methodologies; 
- Expansion of impact of the project beyond its project sites;

- Promotion of synergy and trust building among value chain actors (farmers, transformers, and researchers) and local governments for sharing knowledge;

- Strengthening horizontal and vertical linkages;

- Dissemination of good agricultural and post-harvest practices and innovative technology, for more efficient value chains.

Figure 12. Promotional pro-NUS campaigns carried out by Alexander Coffee in alliance with the project, Bolivia.

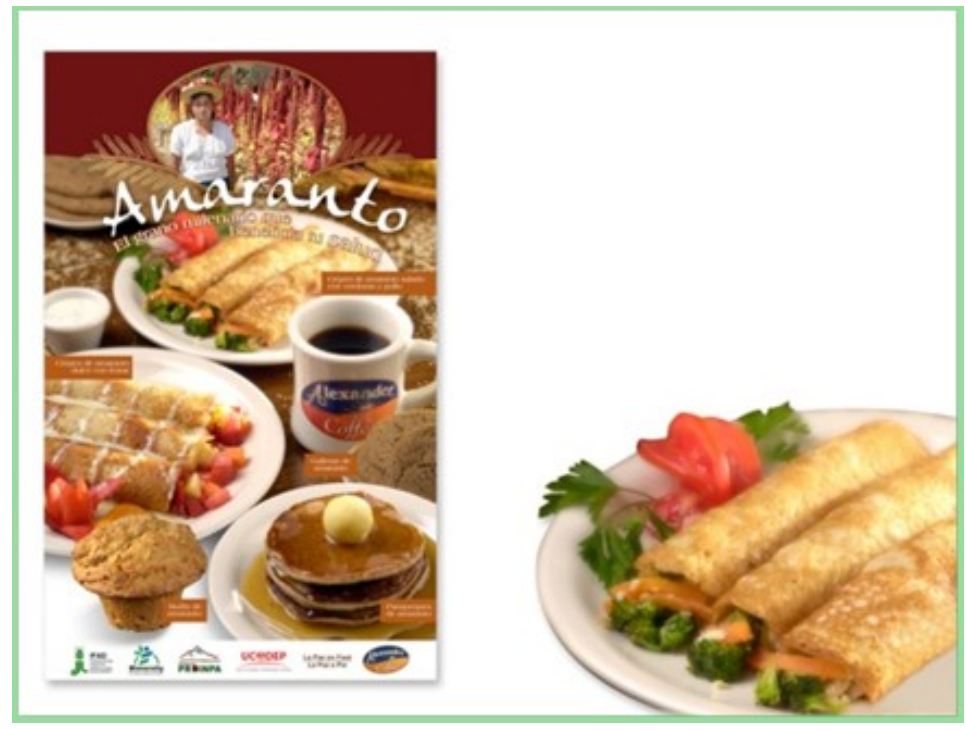

Figure 13. Andean grains collaborative multi-stakeholder platform meeting, Peru.

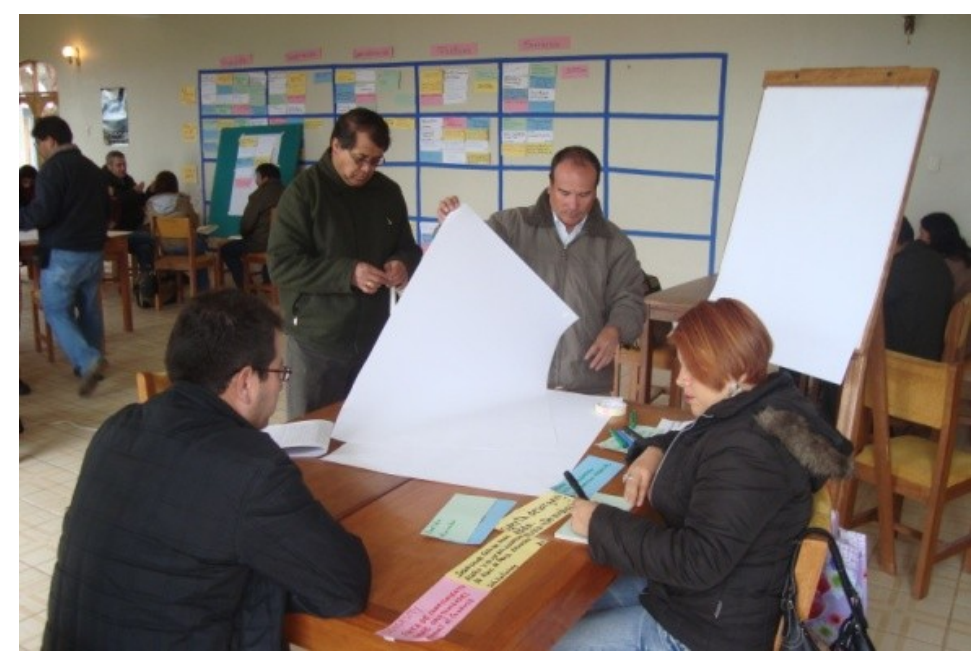

As a concrete outcome from this activity, the case of the Amaranth Platform in Chuquisaca, Bolivia can be highlighted. Here farmers and processors are now effectively interacting in the production and commercialization of amaranth with substantial economic gains compared with previous years. This platform has contributed to important policy changes in their sector such as the successful lobbying for the approval of the National Bolivian Amaranth Development Plan, leveraging its strategic nutritional value and focus on organic production. 


\subsection{Education, Public Awareness and Capacity Building}

During the second phase, nutritional analyses, as well as biochemical characterization of germplasm for polyphenols, antioxidants and other nutraceutical traits were carried out for quinoa, cañahua and amaranth in each country [69-72]. Results of these studies were used to better understand the intra-specific variation of these traits in target crops and support promotional campaigns launched jointly with the private sector.

Capacity building has been a key element throughout the implementation of the project both in Bolivia as well as in Peru through meetings, participatory workshops and field days. Farmers and farmer's associations have been receiving not only training on the nutritional benefits of Andean grains and best cultivation practices (incl. production of quality seeds, pest and disease management and improved harvest and post-harvest methods), but also enhancing their capacities in novel food preparations, transformation processes, nutrition, food safety and marketing [29,37] (see Figure 14). Extension workers and technicians from public and private agencies were also benefiting from these courses. Training courses were providing a special attention to target women, particularly when dealing with nutrition and food preparations.

Figure 14. Capacity building activities in a community variety garden, Santiago de Okola, Bolivia.

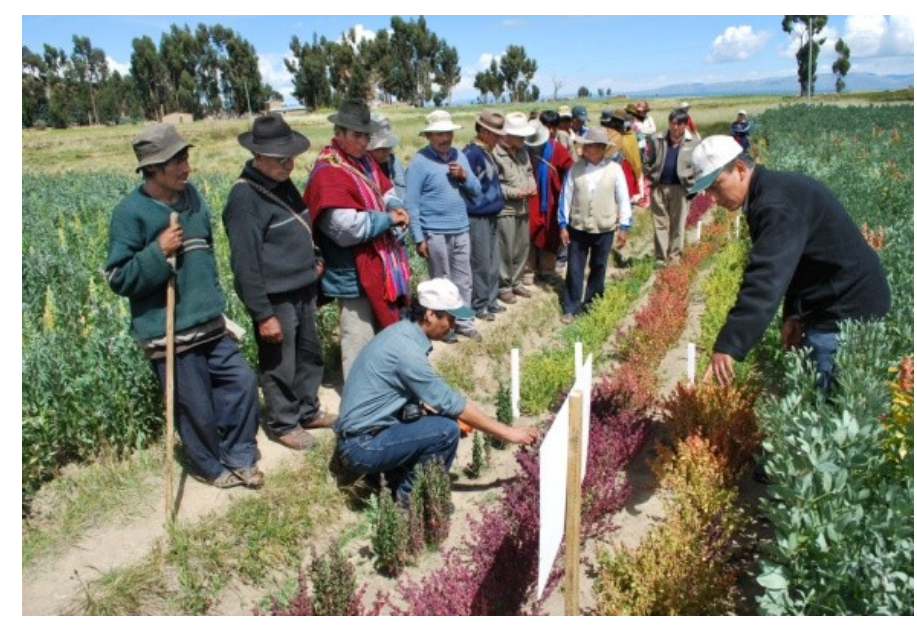

The project gave also support to more than 30 students from local universities in Bolivia and Peru, training them while they were carrying out their research thesis assignments on different topics linked to the IFAD-NUS project [73]. A number of fact sheets, manuals, guidelines, and scientific papers were published for disseminating methods, approaches and tools to practitioners and the scientific community as a whole. In order to make these products easily accessible and at the same time foster knowledge sharing, a web site for the project has been also created [74]. In Bolivia, workshops to sensitize and train at least 15 companies on nutrition, processing practices, marketing, novel product generation and commercialization, and food safety for AG were also carried out.

In order to strengthen further the income generation opportunities from AG for poor rural community members, an innovative "agritourism" approach was successfully introduced in the village of Santiago de Okola in Bolivia. Capacity building of men and women was carried out on agritourism practices and simple infrastructure improvement was made for hosting tourists. Thanks to this initial investment, the community was able to gain attention from a number of funding agencies and 
to establish its own company called "Luisani", build a community museum on agrobiodiversity maintained by the community and organize yearly events to celebrate indigenous crops and food culture [75]. A short article on this work was also prepared by the project for inclusion in the Lonely Planet Guidebook of Bolivia, which proved a very effective way to attract tourists to the village, which has been able to develop and manage its own web site [76].

\subsection{Outcomes and Impact}

In this section we evaluate the impact of the IFAD NUS project in Bolivia and in Peru in terms of consumption, production and marketing of $\mathrm{AG}$ and livelihood indicators using a quasi-experimental design. Data were collected in 2007 and 2010 through a randomized framework of eight communities across Bolivia and Peru that were involved in the project. The analysis assessed the impact of phase I and phase II of the project and their joint effect by comparing livelihood and farming indicators of participating and non-participating households. Figure 15 shows the percentage of households consuming, producing and marketing Andean grains in targeted communities in 2007 and 2010. There are differences among communities but there was a clear increase in these indicators in several communities, in particular in term of production of AG. To understand the role played by the program in these changes a further analysis was performed.

Figure 15. Household consumption, production and marketing of Andean grains across IFAD NUS target communities in the period 2007-2010.
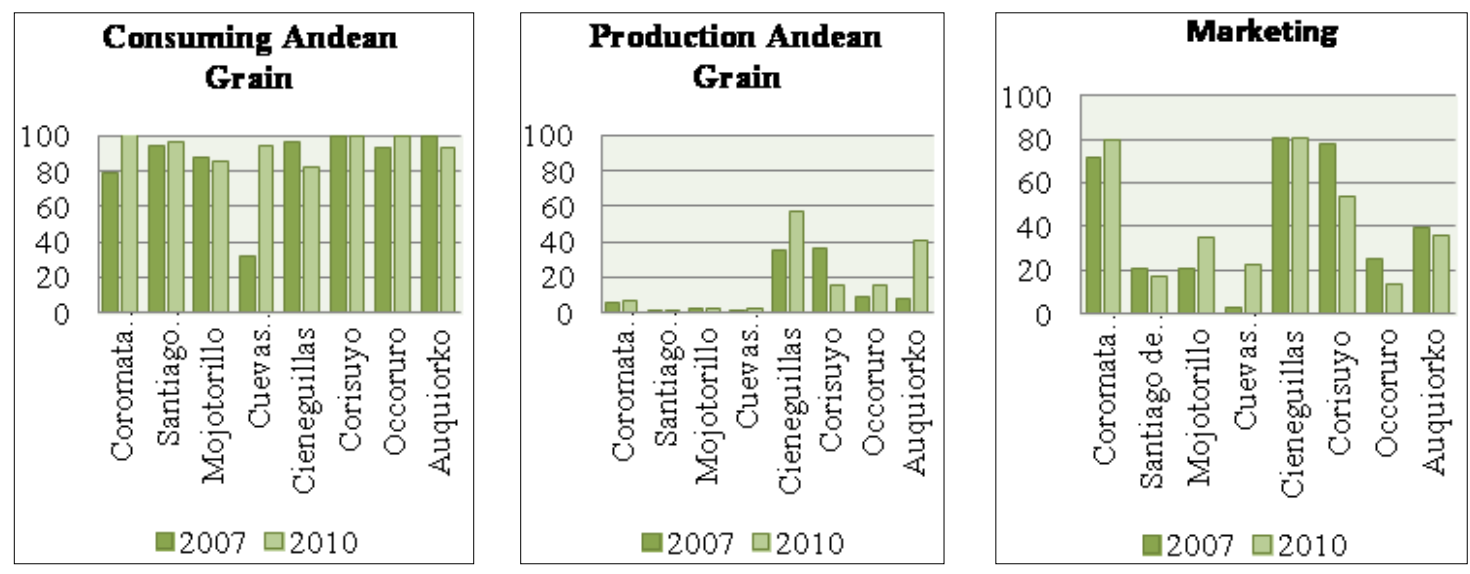

Table 4 reports the estimates in livelihood and farming indicators for households that participated in the project (phase 1, phase 2, or both phases) obtained with propensity scores and Difference in differences method. Only results that were statistically representative with at least a $90 \%$ confidence level are reported.

Participation in the project positively influenced the area planted to Andean grains by households in Peru and Bolivia. In Bolivia, this effect was strongly apparent for households that participated in both phases of the project, whereas in Peru, this effect was most apparent for households who participated in Phase 1 alone. Project interventions positively influenced the richness of AG varieties planted and the number of new varieties introduced by households in Bolivia and, to a lesser extent, in Peru.

In both countries, farmers involved in both phases of the project showed an increase in engagement in the marketing of AG (rated on a 5-item ordinal scale) and a significant increase in perceived 
income. Peruvian households who only participated in the first phase of the project also showed significantly increased marketability of $A G$ and perceived income. As a great surge in demand for quinoa internationally has taken place over the course of the project, it should be emphasized that the perceived increase in marketability of $A G$ by farmers engaged in the project was significantly above that perceived by farmers who were not involved in the project. In Bolivia, significant livelihood benefits of engagement in both phases of the project were apparent through an increased appliance index (an asset-based indicator of wealth built on the availability of eight household appliances that are likely related to the well-being status of the household, inc., refrigerator, mobile phone, and TV).

Table 4. Estimates in farming and livelihood indicators for households that participated in both phases of the IFAD-NUS project.

\begin{tabular}{|c|c|c|c|c|c|c|c|c|}
\hline \multirow{3}{*}{ Indicators } & \multicolumn{2}{|c|}{$\begin{array}{c}\text { Phase } 1 \text { only ** } \\
2007 \text { dataset }\end{array}$} & \multicolumn{4}{|c|}{$\begin{array}{c}\text { Phase } 2 \text { only * } \\
2007 \text { and } 2010 \text { dataset }\end{array}$} & \multicolumn{2}{|c|}{$\begin{array}{c}\text { Both Phase } 1 \text { and } 2 * * \\
2010 \text { dataset }\end{array}$} \\
\hline & \multirow{2}{*}{ Bolivia } & \multirow{2}{*}{ Peru } & \multicolumn{2}{|c|}{ Bolivia } & \multicolumn{2}{|c|}{ Peru } & \multirow{2}{*}{ Bolivia } & \multirow{2}{*}{ Peru } \\
\hline & & & BL & $\mathbf{E L}$ & BL & $\mathbf{E L}$ & & \\
\hline \multicolumn{9}{|c|}{ Andean grain adoption } \\
\hline Area planted to $\mathrm{AG}$ & & 247.961 & & & & & 41.384 & \\
\hline $\begin{array}{l}\text { Number of native } A G \\
\text { varieties planted }\end{array}$ & & & 0.257 & 1.062 & & & 0.981 & \\
\hline $\begin{array}{l}\text { Number of introduced AG } \\
\text { varieties }\end{array}$ & 0.217 & 0.218 & 0.122 & 1.216 & & & 0.908 & \\
\hline $\begin{array}{l}\text { Perceived marketability of } \\
\text { AG (ranked as a 5-item } \\
\text { ordinal scale) }\end{array}$ & & 0.665 & & & & & 0.415 & \\
\hline $\begin{array}{l}\text { Consumption frequency } \\
\text { of AG (ranked on a 6-item } \\
\text { ordinal scale) }\end{array}$ & & & 0.018 & 0.218 & 0.007 & 0.163 & 0.643 & 1.585 \\
\hline \multicolumn{9}{|c|}{ Livelihood measures } \\
\hline Perceived income & & 0.091 & & & & & 54.3 & \\
\hline Appliance index & & 0.090 & & & & & 0.161 & \\
\hline Farm input index & 0.011 & & & & & & & \\
\hline Livestock index & 0.025 & 0.025 & & & & & & \\
\hline Perceived nutrition & & & & & -0.019 & 0.389 & & \\
\hline
\end{tabular}

$\mathrm{BL}=$ baseline; $\mathrm{EL}=$ end line; $\mathrm{NB}$ only results significant at 10\% are reported; * Estimates of Difference in Difference with Kernel Matching (Treatment \#111, Control \#77 for Bolivia and treatment\# 92 control 24 \# for Peru); ** Estimates of Average Treatment of the Treated (ATET) with Kernel Matching (Treatment \#147, Control \#83 for Bolivia and treatment\# 67 and control 88 \# for Peru).

Consumption of Andean grains was already highly prevalent in most communities at the beginning of the project but it was significantly enhanced in both countries through project activities, especially through the second phase, which focused on nutrition and culinary use-enhancement. One community in particular, Cuevas in Bolivia, showed a remarkable increase in Andean grain consumption between 2007 and 2010 (Figure 15). In Peru, the perceived level of nutrition (measured through a 3-items scale 
self-assessment) was strongly enhanced through project activities in the second phase. There was no significant effect of project activities on perceived nutrition of households in Bolivia.

Overall, a positive impact of the project in terms of AG production, conservation, and income benefits was strongly significant and highly robust in Bolivia. These effects were also noted in Peru but were less clear, with more impact on nutrition in this country. The project had a stronger benefit for households that participated in both phases of the project.

Additional indication of project impact on the conservation of diversity of AG is evident through records of the diversity fairs organized in 2008 and 2010 in Santiago de Okola and Coromata Media in Bolivia, which show an increase in the number of native varieties grown by the communities: from 102 to 161 in Coromata Media and from 89 to 131 in Santiago de Okola [77,78].

\section{Conclusions and Way Forward}

Over 10 years the IFAD-NUS project has carried out interventions across the value chains of AG (quinoa, cañahua, and amaranth) to enhance their conservation and leverage their livelihood and nutritional values through greater use. Project activities contributed to strengthen the conservation of their genetic diversity both ex situ and in situ, selected improved varieties, enhanced cultivation practices, developed better harvest and post harvest operations, produced new methods and tools in value addition, enhanced marketing, built capacities and raised public awareness. The innovative and holistic conservation-production-to-consumption approach adopted by the project has demonstrated to be a viable approach to promote the conservation of neglected and underutilized crops, generating at the same time livelihood benefits for poor communities where these resources are intimately connected with local food systems and culture.

This work required the deployment of a methodological framework sensitive to cultural, gender and nutrition aspects and focusing not solely on economic benefits [12]. The establishment of multi-stakeholder platforms at the beginning of project interventions represented a key aspect, which encouraged participation and increased the effectiveness and greater impact [8]. Such holistic farm-to fork value chain approach is both dynamic and fragile, as it is formed by multiple inter-dependent stakeholders, many of which have limited time for building consortia in addition to their farming and domestic activities [26]. A call to policy makers to promote these platforms and lend support to secure their sustainability is thus needed to strengthen horizontal and vertical links of these value chains in the future.

With regard to technological innovations introduced by the project, the popping machine with a Teflon lid could not be adopted extensively by processing companies in Bolivia and Peru. Further efforts are therefore needed to encourage governments to promote this type of technology and implement existing norms regarding safety measures for avoiding led contamination in AG products.

This holistic approach included the conservation of genetic diversity of target crops and their wild relatives as diversity is fundamental to the option value and sustainability of their value chains. To that regard, out of the three AG targeted by the project, quinoa deserves greater attention. The "quinoa boom" is pushing farmers to implement intense cultivations of this crop for meeting the high demands and this is threatening the fragile agro-ecosystems of the Andean Altiplano. Furthermore, the focus of the market almost exclusively on the "Quinoa Real" is determining also the marginalization of hundreds of landraces, whose resilience and nutritional benefits are also being lost [79]. Looking at the 
future prospects of $\mathrm{AG}$, further research on how intrinsic nutritional value of these species can be best managed to meet the increasing demand in functional foods and alternative non-food products (such as the industrial use of saponin for natural cosmetics in the case of quinoa) is also another area where further research is recommended.

\section{Acknowledgments}

The authors would like to thank all the people, from farmers and farmers associations, to women groups, processing companies, private agroindustrial and agritourism companies, chefs, journalists, national and international researchers, foundations, universities, donors, certifying companies, students, national public entities, local, regional and national government officials, among others, that in one way or the other participated in the elaboration, implementation and evaluation of the IFAD-NUS project. We want to warmly thank IFAD for supporting this work as well as many other NUS-focused efforts that are contributing to improve the livelihood of people, especially the poor and vulnerable ones. Authors are also thankful to Vivian Polar and Francesco Caracciolo for their assistance in the generation and analysis of impact data, and to Gennifer Meldrum for helping in the language editing. This paper was developed in the framework of the CGIAR Consortium Program on Policies, Institutions and Markets (PIM).

\section{Author Contributions}

Stefano Padulosi was the global coordinator of the IFAD Project and took the lead in the preparation of the paper; Karen Amaya assisted the lead author in putting together contributions from co-authors, managed layout and final editing; Matthias Jäger provided technical back-stopping to the Project and contributed to the development of the paper; Elisabetta Gotor assisted the Project on the impact evaluation and contributed to writing its dedicated section in the paper; Wilfredo Rojas and Roberto Valdivia coordinated the Bolivian and Peruvian component respectively of the Project and contributed to the development of the paper.

\section{Conflicts of Interest}

The authors declare no conflict of interest.

\section{References}

1. Myers, N.; Mittermeier, R.A.; Mittermeier, C.G.; da Fonseca, G.A.B.; Kent, J. Biodiversity hotspots for conservation priorities. Nature 2000, 403, 853-858.

2. Vavilov, N.I. The Origin, Variation, Immunity and Breeding of Cultivated Plants; The Chronica Botanica Company: Waltham, MA, USA, 1951; p. 364.

3. Food and Agriculture Organization (FAO). La Quinua: Cultivo Milenario para Contribuir a la Seguridad Alimentaria Mundial; FAO, Oficina Regional para América Latina y el Caribe: La Paz, Bolivia, 2011; p. 58. (In Spanish) 
4. The World Bank. Shifting Gears to Accelerate Shared Prosperity in Latin America and the Caribbean. Available online: http://www.worldbank.org/content/dam/Worldbank/document/LAC/ PLB\%20Shared\%20Prosperity\%20FINAL.pdf (accessed on 28 November 2013).

5. Socioeconomic Database for Latin America and the Caribbean SEDLAC. Available online: http://sedlac.econo.unlp.edu.ar/eng/statistics.php (accessed on 28 November 2013).

6. Von Braun, J.; Byerlee, C.; Chartres, C.; Lumpkin, T.; Olembo, N.; Waage, J. Towards a Strategy and Results Framework for the CGIAR. Progress Report No. 4 from the Strategy Team 2009. Available online: https://docs.google.com/viewer?a=v\&pid=sites\&srcid=Y2d4Y2hhbmdlLm9yZ3x hbGxpYW5jZXxneDo3ZGVmZDJjZjI5MmVkMWE (accessed on 28 November 2013).

7. Jacobsen, S.E. The worldwide potential for quinoa (Chenopodium quinoa willd.). Food Rev. Int. 2003, 19, 167-177.

8. Jäger, M.; Valdivia, R.; Padulosi, S.; Arce, J. Lanzamiento de una Plataforma Multiactoral para Promocionar el Uso Sostenible de los Granos Andinos. In Memorias del Foro Realizado en Puno, Perú, 11-13 de Noviembre de 2009; Centro de Investigación de Recursos Naturales y de Medio Ambiente (CIRNMA), Bioversity International, Agencia Suiza para el Desarrollo y la Cooperación (COSUDE): Puno, Peru, 2010; p. 36. (In Spanish)

9. Carrasco, E.; Soto, J.L. Importancia de los Granos Andinos. In Granos Andinos. Avances, Logros y Experiencias Desarrolladas en Quinua, Cañahua y Amaranto en Bolivia; Rojas, W., Soto, J.L., Pinto, M., Jäger, M., Padulosi, S., Eds.; Bioversity International: Rome, Italy, 2010; pp. 6-10. (In Spanish)

10. Tapia, M.E. Origen y Domesticación de las Especies Alimenticias en la Región Andina. In Cultivos Andinos Subexplotados y su Aporte a la Alimentación; FAO: Santiago, Chile, 1990; pp. 17-28. (In Spanish)

11. Astudillo, D.; Aroni, G. Livelihoods of Quinoa Producers in Southern Bolivia. In Biodiversity of Andean Grains: Balancing Market Potential and Sustainable Livelihoods; Giuliani, A., Hintermann, F., Rojas, W., Padulosi, S., Eds.; Bioversity International: Rome, Italy, 2012; pp. 78-145.

12. Padulosi, S.; Bala Ravi, S.; Rojas, W.; Valdivia, R.; Jager, M. Experiences and Lessons Learned in the Framework of a Global UN Effort in Support of Neglected and Underutilized Species. In Proceedings of the 2nd International Symposium on Underutilized Plant Species: Crops for the Future-Beyond Food Security; Massawe, F., Mayes, S., Alderson, P., Eds.; Acta Horticulturae: Leuven, Belgium, 2013; p. 979.

13. Johns, T. Agrobiodiversity Diet and Human Health. In Managing Biodiversity in Agricultural Ecosystems; Jarvis, D.I., Padoch, C., Cooper, H.D., Eds.; Bioversity International: Rome, Italy, 2011; pp. 382-406.

14. Food and Agriculture Organization (FAO). Biodiversity for a World without Hunger. Plants. Available online: http://www.fao.org/biodiversity/components/plants/en/ (accessed on 28 November 2013).

15. Prescott-Allen, R.; Prescott-Allen, C. How many plants feed the world? Conserv. Biol. 1990, 4, $365-374$. 
16. World Health Organization (WHO); United Nations Children's Funds (UNICEF); World Bank; Canadian International Development Agency; US Agency for International Development; Food and Agriculture Organization (FAO); United Nations Development Programme (UNDP). Ending Hidden Hunger. In Proceedings of the Policy Conference on Micronutrient Malnutrition, Montreal, QC, Canada, 10-12 October 1991.

17. United Nations. The Millennium Development Goals Report; United Nations: New York, NY, USA, 2005. Available online: http://unstats.un.org/unsd/mi/pdf/mdg\%20book.pdf (accessed on 28 November 2013).

18. Biesalski, H.K. Hidden Hunger; Springer-Verlag: Berlin, Germany, 2013; p. 255.

19. Food and Agriculture Organization (FAO). Global Plan of Action for the Conservation and Sustainable Utilization of Plant Genetic Resources for Food and Agriculture and the Leipzig Declaration; FAO: Leipzig, Germany, 1996; p. 63.

20. Food and Agriculture Organization (FAO). The Second Global Plan of Action for the Conservation and Sustainable Utilization of Plant Genetic Resources for Food and Agriculture; Commission on Genetic Resources for Food and Agriculture, FAO: Rome, Italy, 2012; p. 91.

21. Food and Agriculture Organization (FAO). The International treaty on Plant Genetic Resources for Food and Agriculture. Available online: http://ftp.fao.org/docrep/fao/011/i0510e/i0510e.pdf (accessed on 28 November 2013).

22. Food and Agriculture Organization (FAO). Cordoba Declaration on Promising Crops for the XXI Century. Available online: http://www.fao.org/fileadmin/templates/food_composition/documents/ Cordoba_NUS_Declaration_2012_FINAL.pdf (accessed on 28 November 2013).

23. Padulosi, S.; Thompson, J.; Rudebjer, P. Fighting Poverty, Hunger and Malnutrition with Neglected and Underutilized Species (NUS): Needs, Challenges and the Way Forward; Bioversity International: Rome, Italy, 2013.

24. Padulosi, S. Neglected No More. Achievements of the IFAD-NUS Project (2001-2005) and Framework for its Follow-up Initiative (2007-2009); Bioversity International: Rome, Italy, 2007; p. 19.

25. Gotor, E.; Caracciolo, F.; Polar, V.; Padulosi, S.; Blundo Canto, G. Assessing the Impact of Research for Development Projects: Bioversity International Programme on Andean Grain in Bolivia and Peru; Bioversity International: Rome, Italy, 2012; p. 16.

26. Mackay, R. External Evaluation IFAD NUS I Project-Asia and Latin America Components; Private Consultancy to the International Fund for Agricultural Development (IFAD): Rome, Italy, 2005; p. 43.

27. Padulosi, S.; Hodgkin, T.; Williams, J.T.; Haq, N. Underutilized Crops: Trends, Challenges and Opportunities in the 21st Century. In Proceedings of the Managing Plant Genetic Diversity Proceedings of an International Conference, Kuala Lumpur, Malaysia, 12-16 June 2000; pp. 323-338.

28. Padulosi, S.; Hoeschle-Zeledon, I. Underutilized plant species: What are they? LEISA 2004, 20, 5-6.

29. Bravo, R.; Valdivia, R.; Andrade, K.; Padulosi, S.; Jäger, M. Granos Andinos. Avances, Logros y Experiencias Desarrolladas en Quinua, Cañihua y Kiwicha en Perú; Bioversity International: Rome, Italy, 2010; p. 127. (In Spanish) 
30. Rojas, W., Soto, J.L., Pinto, M., Jäger, M., Padulosi, S., Eds. Granos Andinos. Avances, Logros y Experiencias Desarrolladas en Quinua, Cañahua y Amaranto en Bolivia; Bioversity International: Rome, Italy, 2010; p. 178. (In Spanish)

31. International Plant Genetic Resources Institute (IPGRI); Fundación para la Promoción e Investigación de Productos Andinos (Fundación PROINPA); International Fund for Agricultural Development (IFAD). Descriptores para cañahua (Chenopodium pallidicaule Aellen); International Plant Genetic Resources Institute: Rome, Italy, 2005; p. 45. (In Spanish)

32. Bioversity International; The Food and Agricultural Organization of the United Nations (FAO); Fundación para la Promoción e Investigación de Productos Andinos (Fundación PROINPA); Instituto Nacional de Innovación Agropecuaria y Forestal (INIAF); Fondo Internacional de Desarrollo Agrícola (FIDA). Descriptores para quinoa (Chenopodium quinoa Willd.) y sus parientes silvestres; Bioversity International/Organización de las Naciones Unidas para la Agricultura y la Alimentación/Fondo Internacional de Desarrollo Agrícola: Roma, Italy; Fundación PROINPA/Instituto Nacional de Innovación Agropecuaria y Forestal: La Paz, Bolivia, 2013; p. 52. (In Spanish)

33. Bravo, R.; Catacora, P. Situación actual de los bancos nacionales de germoplasma. In Granos Andinos. Avances, Logros y Experiencias Desarrolladas en Quinua, Cañahua y Kiwicha en Perú; Rojas, W., Bravo, R., Valdivia, R., Andrade, K., Padulosi, S., Jäger, M., Eds.; Bioversity International: Rome, Italy, 2010; pp. 15-18. (In Spanish)

34. Rojas, W.; Pinto, M.; Bonifacio, A.; Gandarillas, A. Banco de Germoplasma de Granos Andinos. In Granos Andinos. Avances, Logros y Experiencias Desarrolladas en Quinua, Cañahua y Amaranto en Bolivia; Rojas, W., Soto, J.L., Pinto, M., Jäger, M., Padulosi, S., Eds.; Bioversity International: Rome, Italy, 2010; pp. 39-53. (In Spanish)

35. Rojas, W.; Pinto, M. Colecta de germoplasma. In Granos Andinos. Avances, Logros y Experiencias Desarrolladas en Quinua, Cañahua y Amaranto en Bolivia; Rojas, W., Soto, J.L., Pinto, M., Jäger, M., Padulosi, S., Eds.; Bioversity International: Rome, Italy, 2010; pp. 39-53. (In Spanish)

36. Jota, S.M.; Bravo, R. Recetario en Base a Granos Andinos Quinua, Cañihua y Kiwicha. Proyecto Especies Olvidadas y Subutilizadas; Altiplano, E.I.R.L., Ed.; International Fund for Agricultural Development (IFAD): Rome, Italy; Centro de Investigación de Recursos Naturales y Medio Ambiente (CIRNMA)/Centro de Investigación y Capacitación para el Desarrollo Regional (CICADER)/Universidad Nacional del Altiplano (UNA Puno): Puno, Peru, 2010; p. 27. (In Spanish)

37. Mamani, E.; Mamani, R.; Rojas, W. Conocimientos Tradicionales en la Conservación in situ de la Agrobiodiversidad; Fundación para la Promoción e Investigación de Productos Andinos (PROINPA), Bioversity International, Fondo Internacional de Desarrollo Agrícola: La Paz, Bolivia, 2010; p. 20. (In Spanish)

38. Pinto, M.; Miranda, M.; Rojas, W. Reconocimiento al Microcentro de Diversidad de Santiago de Okola. In Informe Enero-Diciembre 2010 Bolivia para el Proyecto Fortalecimiento de las Oportunidades de Ingreso y la Seguridad Nutricional de los Pobres Rurales, a través del Uso y Mercadeo de Especies Olvidadas y Subutilizadas (NUS-IFAD II); Fundación PROINPA: La Paz, Bolivia, 2010; pp. 110-114. (In Spanish) 
39. Rojas, W.; Pinto, M.; Bonifacio, A.; Gandarillas, A. Banco de Germoplasma de Granos Andinos. In Granos Andinos. Avances, Logros y Experiencias Desarrolladas en Quinua, Cañahua y Amaranto en Bolivia; Rojas, W., Soto, J.L., Pinto, M., Jäger, M., Padulosi, S., Eds.; Bioversity International: Rome, Italy, 2010; pp. 24-38. (In Spanish)

40. Gruberg, H.; Meldrum, G.; Padulosi, S.; Rojas, W.; Pinto, M.; Crane, T. Towards a Better Understanding of Custodian Farmers and Their Roles: Insights from a Case Study in Cachilaya, Bolivia; Bioversity International: Rome, Italy; Fundación PROINPA: La Paz, Bolivia, 2013; p. 33.

41. Polar, V.; Rojas, W.; Jäger, M.; Padulosi, S. Taller de Análisis Multiactoral para la Promoción del Uso Sostenible del Amaranto. In Memorias del Taller realizado en Sucre, Bolivia, 19-20 de noviembre de 2009; Fundación PROINPA, Bioversity International: Sucre, Bolivia, 2010; p. 31. (In Spanish)

42. Polar, V.; Rojas, W.; Jäger, M.; Padulosi, S. Taller de Análisis Multiactoral para la Promoción del Uso Sostenible de la Cañahua. In Memorias del Taller Realizado en La Paz, Bolivia, 17 de Noviembre de 2009; Fundación PROINPA, Bioversity International: Sucre, Bolivia, 2010; p. 31. (In Spanish)

43. Instituto Nacional de Innovación Agraria (INIA). Quinua INIA 415 Pasankalla. Variedad para Agroindustria, Exportación y Consumo Nacional; INIA: Lima, Peru, 2006; p. 2. (In Spanish)

44. Pinto, M.; Rojas, W.; Soto, J.L. Variedad de Cañahua Illimani; Fundación PROINPA: La Paz, Bolivia; 2008; p. 4. (In Spanish)

45. Pinto, M.; Rojas, W.; Soto, J.L. Variedad de Cañahua Kullaca; Fundación PROINPA: Cochabamba, Bolivia, 2010; p. 4. (In Spanish)

46. Apaza, V. Manejo y Mejoramiento de Kañiwa; Altiplano, E.I.R.L., Ed.; Convenio Instituto Nacional de Innovación Agraria INIA-Puno/Centro de Investigación de Recursos Naturales y Medio Ambiente (CIRNMA): Puno, Peru; Bioversity International/International Fund for Agricultural Development IFAD: Rome, Italy, 2010; p. 76. (In Spanish)

47. Estrada, R.; Gonza, V.; Gutiérrez, J.L. Guía Práctica Plagas y Enfermedades del Cultivo de Kiwicha (Amaranthus caudatus); Instituto Nacional de Innovación Agropecuaria y Forestal (INIAF): Cuzco, Peru; p. 34. (In Spanish)

48. Mayta Hancco, J. Estudio y Evaluación del Contenido de Plomo Total en Alimentos Procesados en Expansores Tipo Batch Tradicionales; Universidad Nacional del Altiplano, Escuela de Postgrado: Puno, Perú, 2009; p. 117. (In Spanish)

49. Bravo, R.; Valdivia, R. Usos Tradicionales y Nuevos de Quinua, Cañihua y Kiwicha. In Granos Andinos. Avances, Logros y Experiencias Desarrolladas en Quinua, Cañahua y Kiwicha en Perú; Rojas, W., Bravo, R., Valdivia, R., Andrade, K., Padulosi, S., Jäger, M., Eds.; Bioversity International: Rome, Italy, 2010; pp. 91-98. (In Spanish)

50. Pinto, M.; Alarcón, V.; Soto, J.L.; Rojas, W. Usos Tradicionales, No Tradicionales e Innovaciones Agroindustriales de los Granos Andinos. In Granos Andinos. Avances, Logros y Experiencias Desarrolladas en Quinua, Cañahua y Amaranto en Bolivia; Rojas, W., Soto, J.L., Pinto, M., Jäger, M., Padulosi, S., Eds.; Bioversity International: Rome, Italy, 2010; pp. 129-150. (In Spanish)

51. Cuadros, A.; Alpaca, M.C. Elaboración de Néctar de Quinua; Centro de Investigación de Recursos Naturales y de Medio Ambiente (CIRNMA): Puno, Peru, 2010; p. 2. (In Spanish) 
52. Estrada, R.; Gonza, V.; Gutiérrez, J.; Samohuallpa, I. La Kiwicha en la Cocina; Instituto Nacional de Innovación Agropecuaria y Forestal (INIAF): Cuzco, Peru, 2010; p. 28. (In Spanish)

53. Jota, S.M.; Cruz, N. Recetario. Alimentos Ricos y Nutritivos; Centro de Investigación de Recursos Naturales y de Medio Ambiente (CIRNMA): Puno, Peru, 2010; p. 11. (In Spanish)

54. Mujica, A.; Izquierdo, J.; Marathee, J.P.; Capítulo, I. Origen y Descripción de la Quinua. In Quinua (Chenopodium quinoa Willd.). Ancestral Cultivo Andino, Alimento del Presente y Futuro; Mujica, A., Jacobsen, S.E., Izquierdo, J., Marathee, J.P., Eds.; Food and Agricultural Organization of the United Nations (FAO): Santiago de Chile, Chile, 2001. Available online: http://www.rlc.fao.org/es/agricultura/produ/cdrom/contenido/libro03/home03.htm (accessed on 28 November 2013). (In Spanish)

55. Fundación Instituto de Tecnología de Alimentos (ITA). Investigación del Valor Nutricional del Amaranto (Amarantus caudatus) en Grupos Etarios de 0 a 6 Años en las Guarderías del SEDEGES. In the Binational Workshop (Bolivia-Peru) for the Project Fortalecimiento de las Oportunidades de Ingreso y la Seguridad Nutricional de los Pobres Rurales, a través del Uso y Mercadeo de Especies Olvidadas y Subutilizadas (NUS-IFAD II); Fundación PROINPA: Copacabana, Bolivia, 2009. (In Spanish)

56. Aliaga, C.; Serrano, E. Investigación de la Calidad Nutritiva del Amaranto por Edades. In Informe Enero-Diciembre 2010 Bolivia para el Proyecto Fortalecimiento de las Oportunidades de Ingreso y la Seguridad Nutricional de los Pobres rurales, a través del Uso y Mercadeo de Especies Olvidadas y Subutilizadas (NUS-IFAD II); Fundación PROINPA: La Paz, Bolivia, 2010; pp. 22-26. (In Spanish)

57. Fundación PROINPA. Informe Enero-Diciembre 2010 Bolivia para el Proyecto Fortalecimiento de las Oportunidades de Ingreso y la Seguridad Nutricional de los Pobres Rurales, a través del Uso y Mercadeo de Especies Olvidadas y Subutilizadas (NUS-IFAD II); Fundación PROINPA: La Paz, Bolivia, 2010; p. 130. (In Spanish)

58. Villegas, M. Elaboraciones nutricionales de quinua y cañihua en base a análisis químico y evaluación sensorial por niños de hogares de INABIF-Puno; Universidad Nacional del Altiplano UNA-Puno; Escuela Profesional de Nutrición Humana: Puno, Peru, 2008. (In Spanish)

59. Rojas, W.; Pinto, M.; Soto, J.L.; Alcocer, E. Valor nutricional, agroindustrial y funcional de los granos andinos. In Granos andinos. Avances, logros y experiencias desarrolladas en quinua, cañahua y amaranto en Bolivia; Rojas, W., Pinto, J.L., Jäger, M., Padulosi, S., Eds.; Bioversity International: Roma, Italia, 2010. (In Spanish)

60. Tapia, M.E.; Morón, C. Capítulo III. Valor nutritivo de los cultivos andinos subexplotados; Organización de las Naciones Unidas para la Agricultura y la Alimentación FAO: Santiago, Chile, 1990. (In Spanish)

61. McKevith, B. Nutritional aspects of cereals. Nutr. Bull. 2004, 29, 111-142.

62. Cardozo, A.; Tapia, M.; Parte, I. La quinua (Chenopodium quinoa Willd). Valor nutritivo. In $L a$ quinua y la kañiwa. Cultivos andinos; Tapia, M., Gandarillas, H., Alandia, S., Cardozo, A., Mujica, A., Ortiz, R., Otazu, V., Rea, J., Salas, B., Zanabria, E., Eds.; Centro Internacional de Investigaciones para el Desarrollo, Instituto Interamericano de Ciencias Agrícolas: Bogotá, Colombia, 1979. (In Spanish) 
63. Koziol, M. Chemical composition and nutritional evaluation of quinoa (Chenopodium quinoa Willd.). J. Food Compos. Anal. 1992, 5, 35-68.

64. IBNORCA. Catálogo de Normas Bolivianas. Available online: http://www.ibnorca.org/subidas/ catalogo/CATALOGO\%202013_Enero.pdf (accessed on 28 November 2013). (In Spanish)

65. INDECOPI. Tema: Quinua. Available online: http://www.indecopi.gob.pe/0/modulos/TIE/TIE_ BuscarProductos.aspx?TXT=QUINUA\&TIPO=1 (accessed on 28 November 2013). (In Spanish)

66. Centro de Investigación de Recursos Naturales y Medio Ambiente (CIRNMA). Presentación de Resultados Fase II (June 2007-July 2010). In the Taller Final del Proyecto Fortalecimiento de las Oportunidades de Ingreso y la Seguridad Nutricional de los Pobres Rurales, a través del Uso y Mercadeo de Especies Olvidadas y Subutilizadas (IFAD-NUS II); CIRNMA: Copacabana, Bolivia, 2010. (In Spanish)

67. Alexander Coffee. Proyecto Granos Andinos. In the Year 1 Workshop for the Project Fortalecimiento de las Oportunidades de Ingreso y la Seguridad Nutricional de los Pobres Rurales, a través del Uso y Mercadeo de Especies Olvidadas y Subutilizadas (NUS-IFAD II); Alexander Coffee: La Paz, Bolivia, 2008. (In Spanish)

68. Alexander Coffee. Bolivia: Crazy for Quinoa. Available online: http://www.youtube.com/ watch? $\mathrm{v}=\mathrm{z} 4 \mathrm{oZtVmWgOw}$ (accessed on 28 November 2013).

69. Bravo, R. Nuevas Aplicaciones Agroindustriales para Granos Andinos. In the Workshop Proceso Participativo de Planificación Estrategias de Generación de Valor Agregado a través del Uso de la Diversidad de Granos Andinos (Quinua, Kiwicha, Cañihua); Chucuito: Puno, Peru, 2009. (In Spanish)

70. De la Riva, D. Fitatos, Polifenoles y Antioxidantes en Quinua Cruda y Cocida. In Informe Junio 2009-Junio 2010 (año 3) Puno, Perú. Proyecto "Fortalecimiento de las Oportunidades de Ingreso y la Seguridad Nutricional de los Pobres Rurales, a través del Uso y Mercadeo de Especies Olvidadas y Subutilizadas" (NUS-IFAD II); CIRNMA: Puno, Peru, 2010; pp. 35-39. (In Spanish)

71. Mamani, F. Cañahua, Cultivo Originario para la Seguridad Alimentaria. In the Workshop Taller de Análisis Multiactoral para la Promoción del Uso Sostenible de la Cañahua; Fundación PROINPA: La Paz, Bolivia, 2009. (In Spanish)

72. Valdivia, R. Presentación CIRNMA. In the Workshop Proceso Participativo de Planificación Estrategias de Generación de Valor Agregado a través de Uso de la Diversidad de Granos Andinos (Quinua, Kiwicha, Cañihua); Chucuito: Puno, Peru, 2009. (In Spanish)

73. Investigaciones sobre Especies Olvidadas y Subutilizadas. Granos Andinos (Quinua, Cañahua/Cañihua y Amaranto/Kiwicha). In Resúmenes de trabajos de Grados y Tesis de Maestría realizadas en Bolivia y Perú (2001-2010); Bravo, R., Andrade, K., Valdivia, R., Soto, J.L., Eds.; Bioversity International: Rome, Italy, 2010; p. 181. (In Spanish)

74. Neglected and underutilized species: The IFAD NUS Project to share experiences, lessons learnt and promotes networking. Available online: http://www.nuscommunity.org/ (accessed on 28 November 2013).

75. Taranto, S.; Padulosi, S. Testing the results of a joint effort. LEISA 2009, 25, 32-33.

76. Santiago de Okola. The Community of Santiago de Okola (Lake Titicaca, Bolivia). Available online: http://www.santiagodeokola.com (accessed on 28 November 2013). (In Spanish) 
77. Mamani, E.; Rojas, W. Concursos de Agrobiodiversidad de Cultivos Andinos en las Comunidades de Coromata Media y Santiago de Okola. In Informe Técnico Anual 2009. Proyecto "Elevar la Contribución que Hacen las Especies Olvidadas y Subutilizadas a la Seguridad Alimentaria y a los Ingresos de la Población de Escasos Recursos" (NUS-IFAD); Fundación PROINPA: La Paz, Bolivia, 2009; pp. 119-129. (In Spanish)

78. Pinto, M.; Alarcón, V.; Miranda, M. Concursos de Agrobiodiversidad de los Cultivos Andinos en las Comunidades de Coromata Media y Santiago de Okola. In Informe Enero-Diciembre 2010 Bolivia. Proyecto Fortalecimiento de las Oportunidades de Ingreso y la Seguridad Nutricional de los Pobres Rurales, a través del Uso y Mercadeo de Especies Olvidadas y Subutilizadas (NUS-IFAD II); Fundación PROINPA: La Paz, Bolivia, 2010; pp. 51-66. (In Spanish)

79. Giuliani, A., Hintermann, F., Rojas, W., Padulosi, S., Eds. Biodiversity of Andean Grains: Balancing Market Potential and Sustainable Livelihoods; Bioversity International: Rome, Italy, 2012; p. 198.

(C) 2014 by the authors; licensee MDPI, Basel, Switzerland. This article is an open access article distributed under the terms and conditions of the Creative Commons Attribution license (http://creativecommons.org/licenses/by/3.0/). 